\title{
Structural Characterization of Molybdenum Oxide Supported on Zirconia
}

\author{
Shuibo Xie, Kaidong Chen, Alexis T. Bell,* and Enrique Iglesia* \\ Chemical and Materials Sciences Divisions, E. O. Lawrence Berkeley National Laboratory, and \\ Department of Chemical Engineering, University of California, Berkeley, California 94720-1462
}

Received: July 6, 2000

\begin{abstract}
$\mathrm{X}$-ray diffraction and X-ray absorption and Raman spectroscopies were used to determine the structure of dispersed and crystalline structures in $\mathrm{MoO}_{x} / \mathrm{ZrO}_{2}$ catalysts useful in the oxidative dehydrogenation of alkanes. The $\mathrm{MoO}_{x}$ surface density on $\mathrm{ZrO}_{2}$ was varied over a wide range $\left(0.35-50 \mathrm{Mo} / \mathrm{nm}^{2}\right)$ by changing the Mo content $\left(1-44 \mathrm{wt} \% \mathrm{MoO}_{3}\right)$ and the treatment temperature $(393-973 \mathrm{~K})$. Raman spectra showed that $\mathrm{MoO}_{x} /$ $\mathrm{ZrO}_{2}$ samples with low surface density $\left(<5 \mathrm{Mo} / \mathrm{nm}^{2}\right)$ treated at temperatures below $873 \mathrm{~K}$ initially contain isolated tetrahedral $\mathrm{MoO}_{x}$ species; these species oligomerize to form two-dimensional structures with bridging $\mathrm{Mo}-\mathrm{O}-\mathrm{Mo}$ bonds as the surface density increased to values typical for a polymolybdate monolayer ( $\sim 5$ $\left.\mathrm{Mo} / \mathrm{nm}^{2}\right)$. An increase in surface density led to a shift in the $v(\mathrm{Mo}=\mathrm{O})$ Raman band to higher frequencies and to changes in the near-edge X-ray absorption spectra. Both of these are consistent with the growth of these polymolybdate domains with increasing Mo surface density, as also suggested by the concurrent decrease in the UV-visible absorption energy. Thermal treatment at $973 \mathrm{~K}$ led to the dissociation of $\mathrm{Mo}-\mathrm{O}-\mathrm{Mo}$ bonds and to the formation of tetragonal-pyramidal $\mathrm{O}=\mathrm{MoO}_{4}$ species. For $\mathrm{MoO}_{x} / \mathrm{ZrO}_{2}$ samples with Mo surface densities greater than $5 \mathrm{Mo} / \mathrm{nm}^{2}, \mathrm{MoO}_{3}$ and $\mathrm{Zr}\left(\mathrm{MoO}_{4}\right)_{2}$ were detected by Raman and for larger crystallites also by X-ray diffraction. Treatment of these samples in air at $723 \mathrm{~K}$ led to the predominant formation of $\mathrm{MoO}_{3}$, while higher temperatures led to a solid-state reaction between $\mathrm{MoO}_{3}$ and $\mathrm{ZrO}_{2}$ to form $\mathrm{Zr}\left(\mathrm{MoO}_{4}\right)_{2}$. This structural evolution was confirmed by the evolution of pre-edge and near edge features in the X-ray absorption spectra of these high surface density samples. $\mathrm{Zr}\left(\mathrm{MoO}_{4}\right)_{2}$ contains $\mathrm{Mo}^{6+}$ cations in a distorted tetrahedral coordination with one oxygen bonded only to molybdenum and the other three shared by $\mathrm{Zr}$ and Mo atoms. The Raman bands observed for $\mathrm{Zr}\left(\mathrm{MoO}_{4}\right)_{2}$ at 750, 945, and $1003 \mathrm{~cm}^{-1}$ were assigned to $v_{\text {sym }}(\mathrm{O}-\mathrm{Mo}-\mathrm{O}), v_{\text {asym }}(\mathrm{O}-\mathrm{Mo}-\mathrm{O})$, and $v(\mathrm{Mo}=\mathrm{O})$ vibrational modes, respectively, based on the analysis of the Raman bands observed after ${ }^{18} \mathrm{O}_{2}$ exchange with lattice oxygen atoms. Bridging $\mathrm{O}$ atoms in $\mathrm{Mo}-\mathrm{O}-$ Mo species exchanged with gas phase ${ }^{18} \mathrm{O}_{2}$ more readily than terminal $\mathrm{Mo}=\mathrm{O}$ species.
\end{abstract}

\section{Introduction}

The thermodynamic feasibility of oxidative dehydrogenation $(\mathrm{ODH})$ of alkanes has led to extensive evaluation of oxide catalysts for these reactions. Supported vanadium and molybdenum oxides have been widely used for selective oxidation reactions. ${ }^{1-10}$ Recently, propane $\mathrm{ODH}$ rates and selectivity on $\mathrm{MoO}_{x} / \mathrm{ZrO}_{2}$ catalysts were shown to depend strongly on the $\mathrm{MoO}_{x}$ surface density, which was varied by changing the Mo content and the catalyst treatment temperature. ${ }^{11}$ The evolution of the structure of $\mathrm{ZrO}_{2}$-supported molybdenum oxide from isolated $\mathrm{MoO}_{x}$ to two-dimensional oligomers and ultimately to $\mathrm{MoO}_{3}$ or $\mathrm{Zr}\left(\mathrm{MoO}_{4}\right)_{2}$ bulk structures depends on the Mo surface density, the treatment temperature, and the reactivity of the support. Here, we report the details of this structural evolution. $\mathrm{ZrO}_{2}$-supported $\mathrm{MoO}_{x}$ with Mo surface densities ranging from 0.35 to $50 \mathrm{Mo} / \mathrm{nm}^{2}$ were characterized by Raman spectroscopy, $\mathrm{X}$-ray diffraction, and X-ray absorption spectroscopy in order to understand how their structures evolved during catalyst synthesis and pretreatment. Raman spectroscopy probes the vibrational modes and thus the local structure and metal-oxygen bond strength in dispersed oxide domains. ${ }^{12-15} \mathrm{X}$-ray absorption spectroscopy (XAS) is a direct probe of the atomic environment and it provides chemical bonding information, such as coordina-

* To whom correspondence should be addressed. E-mail: Iglesia@ cchem.berkeley.edu; Bell@ cchem.berkeley.edu. tion numbers and interatomic distances of neighboring atoms around the absorber. ${ }^{16}$

\section{Experimental Section}

The syntheses of the zirconia support and of $\mathrm{MoO}_{x} / \mathrm{ZrO}_{2}$ catalysts have been reported elsewhere. ${ }^{11}$ Hydrous zirconium oxyhydroxide, $\mathrm{ZrO}_{x}(\mathrm{OH})_{4-2 x}$, was precipitated at a $\mathrm{pH}$ of 10 from a $1 \mathrm{M}$ aqueous solution of zirconyl chloride by controlled addition of ammonium hydroxide solutions. After precipitation, the solids were washed with mildly basic ammonium hydroxide solution $(\mathrm{pH} \sim 8)$ until $\mathrm{AgCl}$ precipitates were no longer detected in the effluent by the dropwise addition of a $3 \mathrm{M}$ $\mathrm{AgNO}_{3}$ solution $\left(\left[\mathrm{Cl}^{-}\right]<10^{-10} \mathrm{M}\right)$. The precipitated powders were dried in air overnight at $393 \mathrm{~K}$. $\mathrm{MoO}_{x} / \mathrm{ZrO}_{2}$ samples were prepared by incipient wetness impregnating the $\mathrm{ZrO}_{x}(\mathrm{OH})_{4-2 x}$ powders dried at $393 \mathrm{~K}$ with a solution of ammonium dimolybdate (Aldrich, 99\%) or ammonium heptamolybdate (Aldrich, $99 \%$ ). The $\mathrm{Mo}^{6+}$ concentration in the impregnating solution was varied in order to achieve the desired Mo content. After impregnation, samples were dried overnight in air at $393 \mathrm{~K}$ and then treated in flowing dry air at 723,773 , or $873 \mathrm{~K}$ for $3 \mathrm{~h}$ before reaction and characterization measurements.

Raman spectra were recorded using a HoloLab 5000 Raman spectrometer (Kaiser Optical) equipped with a Nd:YAG laser frequency-doubled to $532 \mathrm{~nm}$ and using a spectral resolution of $5 \mathrm{~cm}^{-1}$. The laser was operated with a power level of 45 
$\mathrm{mW}$, measured at the sample position with an optical power meter (Edmund Scientific). Samples ( $\sim 50 \mathrm{mg}$ ) were pressed into a $9 \mathrm{~mm}$ diameter wafer at $350 \mathrm{MPa}$ and placed within a Raman quartz flow cell. The wafers can be heated to $1073 \mathrm{~K}$ within the cell using a heating wire wound around the cell. The effect of laser heating was minimized by rotating the sample at $20 \mathrm{~Hz}$. Raman spectra were recorded at $298 \mathrm{~K}$ after samples initially dried at $393 \mathrm{~K}$ were treated in $20 \% \mathrm{O}_{2} / \mathrm{He}$ (Scott Specialty Gases) at a given temperature for $1 \mathrm{~h}$.

Mo K-edge X-ray absorption (XAS) spectra were measured using beamline 4-1 at the Stanford Synchrotron Radiation Laboratory (SSRL). The samples were diluted with boron nitride (BN) to about 5 wt $\% \mathrm{MoO}_{3}$, and they were then pressed into wafers, crushed, and sieved to retain particles with $0.18-0.25$ $\mathrm{mm}$ diameter. These particles were placed within a thin quartz capillary tube $(1.0 \mathrm{~mm}$ diameter; $0.1 \mathrm{~mm}$ wall thickness) and supported horizontally in the path of the rectangular X-ray beam $(0.2 \mathrm{~mm} \times 6.0 \mathrm{~mm})$. The details of the in situ XAS cell used in XAS experiments were described elsewhere. ${ }^{17}$ Transmission spectra were measured using Ar flow in three ion chamber detectors; one chamber was located before the sample to measure the incident X-ray intensity $\left(\mathrm{I}_{0}\right)$, one after the sample and before a Mo foil $(7.5 \mu)$ to measure the intensity after absorption $\left(\mathrm{I}_{1}\right)$, and one after the Mo foil in order to calibrate the energy scale $\left(\mathrm{I}_{2}\right)$. The sample spectra and the Mo foil reference spectra are reported as $\log \left(\mathrm{I}_{0} / \mathrm{I}_{1}\right)$ and $\log \left(\mathrm{I}_{1} / \mathrm{I}_{2}\right)$, respectively. The energy was calibrated using the first inflection point in the Mo foil spectrum (19.999 keV). Spectra were measured using a $\mathrm{Si}^{220}$ crystals monochromator with $5 \mathrm{eV}$ energy increments in the pre-edge region (19.875-19.975 keV), $0.25 \mathrm{eV}$ increments in the edge region $(19.975-20.035 \mathrm{keV})$, and $0.04 \AA^{-1}$ in the fine structure region $(20.035-21.024 \mathrm{keV})$. $\mathrm{X}$-ray absorption data were analyzed using WinXAS software (version 1.2). ${ }^{18,19}$ A linear fit to the pre-edge region was subtracted from the entire spectrum, and then the spectrum was normalized using a fifth-order polynomial fit to the post-edge fine structure (EXAFS) region.

Powder X-ray diffraction (XRD) patterns were measured at ambient conditions using a Siemens D-5000 diffractometer and $\mathrm{Cu}(\mathrm{K} \alpha)$ radiation. A small amount of sample was distributed on a glass plate holder using a thin layer of Vaseline.

\section{Results and Discussion}

$\mathrm{MoO}_{x}$ Surface Density. The Mo surface densities per unit surface area were calculated from the $\mathrm{MoO}_{3}$ concentration and the BET surface area measured using $\mathrm{N}_{2}$ physisorption at 77 $\mathrm{K}$; they are reported as the number of Mo atoms per $\mathrm{nm}^{2}$ surface area $\left(\mathrm{Mo} / \mathrm{nm}^{2}\right) .{ }^{11}$ The Mo surface densities for $\mathrm{MoO}_{x} / \mathrm{ZrO}_{2}$ with varying Mo concentrations after treatment in dry air at 723 , 773 , or $873 \mathrm{~K}$ are shown in Figure 1. The polymolybdate saturation capacity on several metal oxide supports has been reported to be $\sim 5 \mathrm{Mo} / \mathrm{nm}^{2}$, from equilibrium adsorption measurement from aqueous molybdate solutions, ${ }^{20-22} \mathrm{X}$-ray diffraction, ${ }^{23-27}$ and X-ray photoelectron spectroscopy. ${ }^{28,29}$ Those experimental results are in agreement with the theoretical monolayer coverage of $4.9 \mathrm{Mo} / \mathrm{nm}^{2}$ calculated from the effective ionic diameter of $\mathrm{MoO}_{6}$ octahedra. ${ }^{30}$ It is apparent from Figure 1 that Mo surface densities for all $\mathrm{MoO}_{x} / \mathrm{ZrO}_{2}$ samples with Mo contents below $11 \mathrm{wt} \% \mathrm{MoO}_{3}$ are below this monolayer capacity

Bulk Structure of $\mathrm{ZrO}_{2}$ and $\mathrm{MoO} / \mathrm{ZrO}_{2}$ Samples Detected by X-ray Diffraction. The bulk structures of pure $\mathrm{ZrO}_{2}$ and of supported $\mathrm{MoO}_{x} / \mathrm{ZrO}_{2}$ catalysts were determined by powder X-ray diffraction. X-ray diffraction patterns are shown

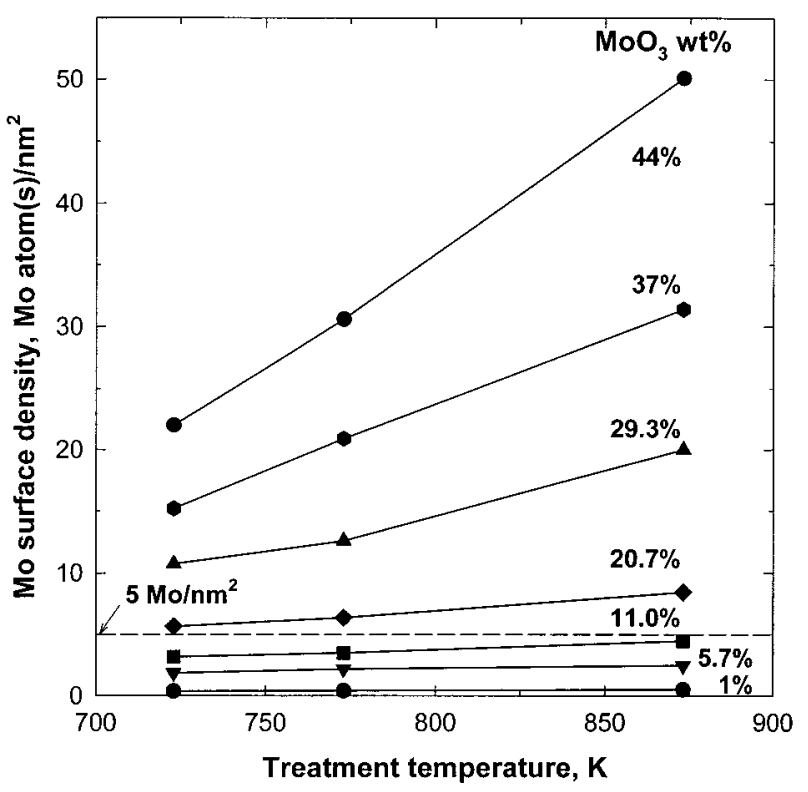

Figure 1. Mo surface densities of $\mathrm{MoO}_{x} / \mathrm{ZrO}_{2}$ catalysts with different $\mathrm{MoO}_{3}$ loadings after treatment in dry air at 723,773 , and $873 \mathrm{~K}$. The dashed line represents the $\mathrm{MoO}_{x}$ surface density corresponding to monolayer coverage, $5 \mathrm{Mo} / \mathrm{nm}^{2}$.

in Figures 2A for the $\mathrm{ZrO}_{2}$ support treated in air at 723, 773, or $873 \mathrm{~K}$. Both tetragonal and monoclinic $\mathrm{ZrO}_{2}$ phases were detected in all pure $\mathrm{ZrO}_{2}$ samples and the monoclinic fraction increased with increasing treatment temperature (Figure 2D). Raman spectroscopy showed that amorphous $\mathrm{ZrO}_{x}(\mathrm{OH})_{4-2 x}$ begins to crystallize into tetragonal $\mathrm{ZrO}_{2}$ at $673 \mathrm{~K}$ in $20 \% \mathrm{O}_{2} /$ $\mathrm{He}$; the tetragonal $\mathrm{ZrO}_{2}$ formed is stable in dry air at temperatures up to $873 \mathrm{~K}^{31}$ No monoclinic $\mathrm{ZrO}_{2}$ was detected in Raman experiments after amorphous $\mathrm{ZrO}_{x}(\mathrm{OH})_{4-2 x}$ was treated within the Raman cell in flowing $20 \% \mathrm{O}_{2} / \mathrm{He}$ at $873 \mathrm{~K}$ for $2 \mathrm{~h}$ (spectra not shown). Tetragonal $\mathrm{ZrO}_{2}$, however, transformed into the monoclinic phase rapidly at room temperature when exposed to moist ambient air or to a $\mathrm{H}_{2} \mathrm{O}$ vapor. ${ }^{31}$ Clearly, X-ray diffraction detects monoclinic $\mathrm{ZrO}_{2}$ because some tetragonal $\mathrm{ZrO}_{2}$ converted to monoclinic when samples were exposed to moist ambient air during sample preparation and XRD measurements.

The incorporation of cations such as $\mathrm{Mg}^{2+}, \mathrm{Ca}^{2+}, \mathrm{Y}^{3+}, \mathrm{La}^{3+}$, $\mathrm{Ce}^{4+}, \mathrm{W}^{6+}$, and $\mathrm{V}^{5+}$, into $\mathrm{ZrO}_{2}$ inhibits the crystallization of amorphous $\mathrm{ZrO}_{x}(\mathrm{OH})_{4-2 x}$ into tetragonal $\mathrm{ZrO}_{2}$ and the conversion of tetragonal $\mathrm{ZrO}_{2}$ to the monoclinic phase. ${ }^{10,32,33}$ The X-ray diffraction patterns for $1 \mathrm{wt} \% \mathrm{MoO}_{x} / \mathrm{ZrO}_{2}$ suggest that tetragonal $\mathrm{ZrO}_{2}$ is the predominant $\mathrm{ZrO}_{2}$ phase; the volume fraction of monoclinic phase is $0.2,0.31$, and 0.4 for samples treated at 723, 773, and $873 \mathrm{~K}$, respectively (Figure 2D). As the $\mathrm{MoO}_{3}$ content increased to $11 \mathrm{wt} \%$, only tetragonal $\mathrm{ZrO}_{2}$ was detected in samples treated at 723-973 K (Figure 2B). At higher $\mathrm{MoO}_{3}$ contents ( $37 \mathrm{wt} \%$ ), both crystalline $\mathrm{MoO}_{3}$ and $\mathrm{Zr}\left(\mathrm{MoO}_{4}\right)_{2}$ structures were detected along with some tetragonal $\mathrm{ZrO}_{2}$ in samples treated at 723 or $773 \mathrm{~K}$. The relative intensity of the $\mathrm{Zr}\left(\mathrm{MoO}_{4}\right)_{2}$ peaks increased with increasing treatment temperature (Figure 2C). Only crystalline $\mathrm{Zr}\left(\mathrm{MoO}_{4}\right)_{2}$ was detected after a $37 \mathrm{wt} \% \mathrm{MoO}_{3} / \mathrm{ZrO}_{2}$ sample was treated at 873 $\mathrm{K}$ for $3 \mathrm{~h}$ (surface density $32 \mathrm{Mo} / \mathrm{nm}^{2}$ ), suggesting that all $\mathrm{MoO}_{3}$ reacts with $\mathrm{ZrO}_{2}$ to form crystalline $\mathrm{Zr}\left(\mathrm{MoO}_{4}\right)_{2}$ at this temperature.

Solid-State Reactions of Crystalline $\mathrm{MoO}_{3}$ with $\mathrm{ZrO}_{2}$. The formation of $\mathrm{Zr}\left(\mathrm{MoO}_{4}\right)_{2}$ via solid-state reactions of $\mathrm{MoO}_{3}$ and $\mathrm{ZrO}_{2}$ was studied using an intimate physical mixture of 

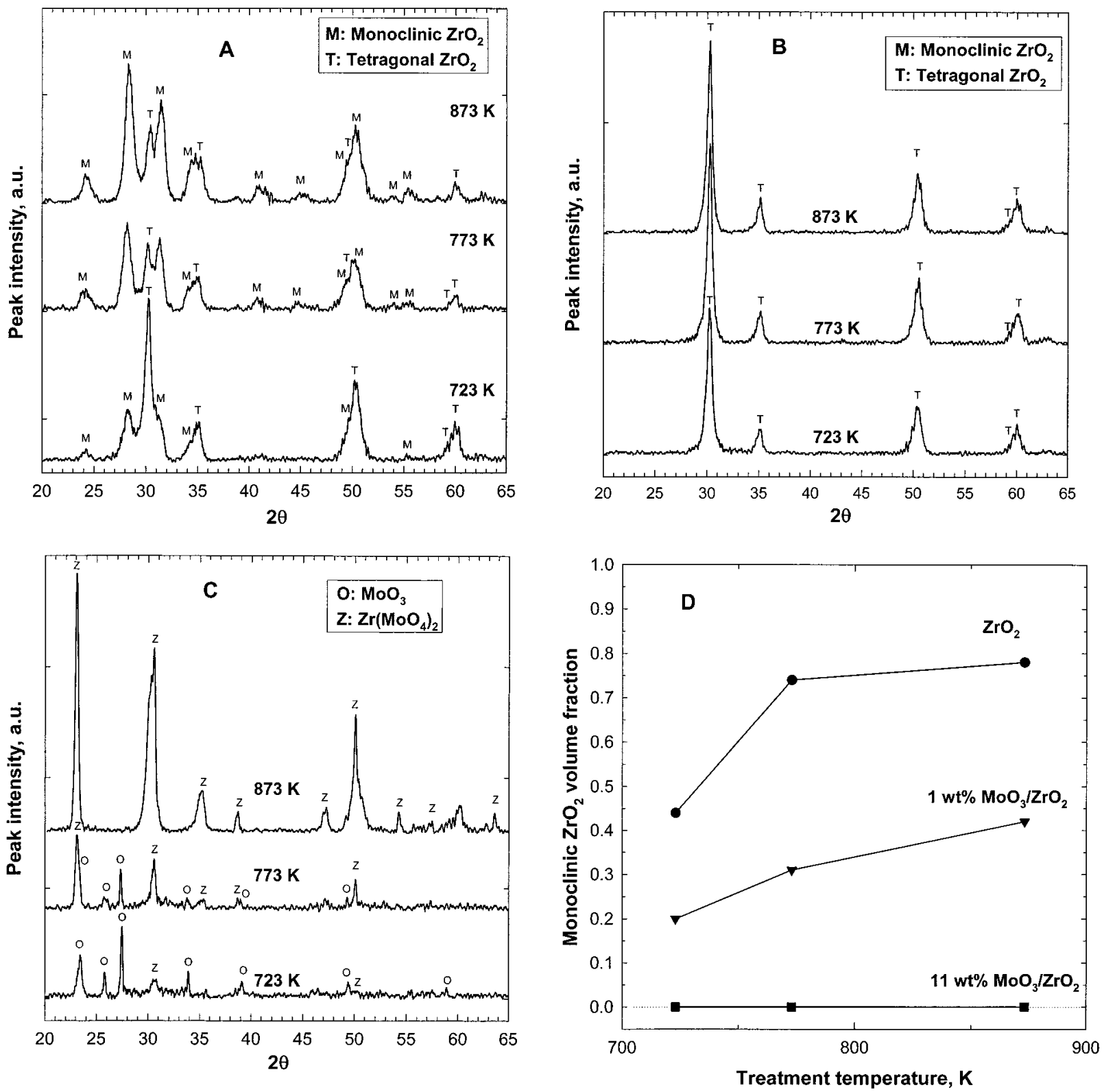

Figure 2. X-ray diffraction patters for pure $\mathrm{ZrO}_{2}$ and $\mathrm{MoO}_{x} / \mathrm{ZrO}_{2}$ samples calcined in dry air at 723, 773, and $873 \mathrm{~K}$ : (A) pure $\mathrm{ZrO}$; (B) 11 wt $\% \mathrm{MoO}_{x} / \mathrm{ZrO}_{2}$; (C) 37 wt $\% \mathrm{MoO}_{x} / \mathrm{ZrO}_{2}$. (D) Monoclinic $\mathrm{ZrO}_{2}$ fraction in total $\mathrm{ZrO}_{2}$ as functions of $\mathrm{MoO}_{3}$ loading and treatment temperature.

crystalline $\mathrm{MoO}_{3}$ and $\mathrm{ZrO}_{x}(\mathrm{OH})_{4-2 x}$ with the expected stoichiometry of $\mathrm{Zr}\left(\mathrm{MoO}_{4}\right)_{2}(\mathrm{Mo} / \mathrm{Zr}=2)$. This mixture was mixed thoroughly by grinding with a mortar and a pestle for $\sim 0.3 \mathrm{~h}$ in order to ensure homogeneity. It was then heated in $20 \% \mathrm{O}_{2}$ at $10 \mathrm{~K} / \mathrm{min}$ with isothermal holds at specific temperatures; the resulting structural evolution was followed by Raman spectroscopy. The spectrum of this mixture at $298 \mathrm{~K}$ is identical to that for pure crystalline $\mathrm{MoO}_{3},{ }^{14}$ with characteristic Raman bands at $118,131,159,201,220,248,287,340,370,382,474,668$, 821 , and $998 \mathrm{~cm}^{-1}$ (spectrum a in Figure 3A). No new bands appeared after treating this mixture at $673 \mathrm{~K}$ for $1 \mathrm{~h}$ in $20 \%$ $\mathrm{O}_{2} / \mathrm{He}$. The treatment at $773 \mathrm{~K}$ for $1 \mathrm{~h}$ led to the appearance of two weak bands at $\sim 741$ and $943 \mathrm{~cm}^{-1}$ (spectra not shown), which suggest the formation of a new structure, apparently $\mathrm{Zr}$ $\left(\mathrm{MoO}_{4}\right)_{2}$. The growth of these bands is very slow at $773 \mathrm{~K}$ and even at $873 \mathrm{~K}$, but these bands became significantly more intense after heating at $973 \mathrm{~K}$. At $973 \mathrm{~K}$, the Raman bands at $141,195,232,279,373,466,660$, and $820 \mathrm{~cm}^{-1}$, corresponding to crystalline $\mathrm{MoO}_{3}$, weakened with time and ultimately disappeared after $\sim 0.25$ h (Figure $3 B$ ). Concurrently, Raman bands at 736 and $939 \mathrm{~cm}^{-1}$, corresponding to the new Mo compound, became more intense and then remained unchanged after the initial $0.25 \mathrm{~h}$. After $\sim 0.7 \mathrm{~h}$ at $973 \mathrm{~K}$, the band at 334 $\mathrm{cm}^{-1}$ shifted to $333 \mathrm{~cm}^{-1}$ and the band at $990 \mathrm{~cm}^{-1}$ decreased in intensity during the first $0.25 \mathrm{~h}$ and then shifted to $983 \mathrm{~cm}^{-1}$ at longer times. The spectrum recorded at $298 \mathrm{~K}$ for this $\mathrm{MoO}_{3}-$ $\mathrm{ZrO}_{2}$ mixture after treatment at $973 \mathrm{~K}$ is shown in Figure $3 \mathrm{~A}$ (spectra b). It shows strong Raman bands at 177, 328, 361, 750, 945 , and $1003 \mathrm{~cm}^{-1}$. The absence of characteristic bands for crystalline $\mathrm{MoO}_{3}$ or $\mathrm{ZrO}_{2}$ suggests that the solid-state reaction is complete. The frequencies of Raman bands for $\mathrm{MoO}_{3}$ and $\mathrm{Zr}\left(\mathrm{MoO}_{4}\right)_{2}$ in the spectra measured at $973 \mathrm{~K}$ (Figure 3B) are lower than those found in spectra measured at $298 \mathrm{~K}$ (Figure $3 \mathrm{~B})$, reflecting the contraction of $\mathrm{MoO}_{3}$ and $\mathrm{Zr}\left(\mathrm{MoO}_{4}\right)_{2}$ crystalline lattice with decreasing temperature. ${ }^{34}$

The stable structure of $\mathrm{Zr}\left(\mathrm{MoO}_{4}\right)_{2}$ at $973 \mathrm{~K}$ is hexagonal with two-dimensional networks of $\mathrm{MoO}_{4}$ tetrahedra and $\mathrm{ZrO}_{6}$ octahedra (as illustrated in Figure 4). ${ }^{35}$ The distance between two layers is $5.85 \AA$ and neighboring layers interact via van der Waals forces between $\mathrm{O}$ atoms in different layers. The $\mathrm{Mo}^{6+}$ 

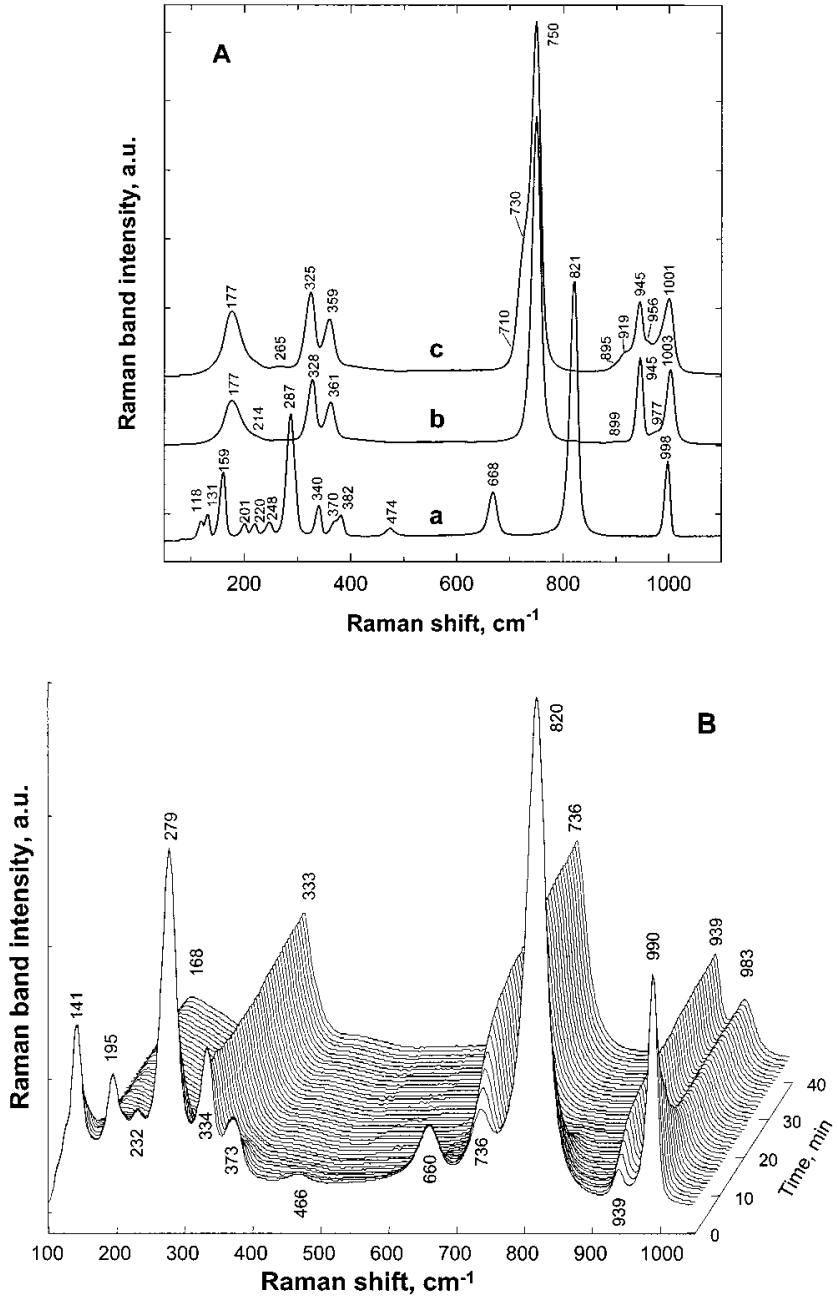

Figure 3. Raman spectra recorded for a physical mixture of $\mathrm{MoO}_{3}$ and $\mathrm{ZrO}_{x}(\mathrm{OH})_{4-2 x}(\mathrm{Mo} / \mathrm{Zr}$ atomic ratio $=2: 1)$. (A) a, before treatment at high temperatures; b, after treatment at $973 \mathrm{~K}$ in $20 \% \mathrm{O}_{2} / \mathrm{He}$ for 40 min; c, after evacuated at $973 \mathrm{~K}$ for $2 \mathrm{~min}$ and then equilibrated in 69 $\mathrm{kPa}{ }^{18} \mathrm{O}_{2}$ at $1023 \mathrm{~K}$ for $15 \mathrm{~min}$. All spectra were recorded at $298 \mathrm{~K}$. (B) Spectra recorded during treatment in $20 \% \mathrm{O}_{2}$ at $973 \mathrm{~K}$ with intervals of 1 min.

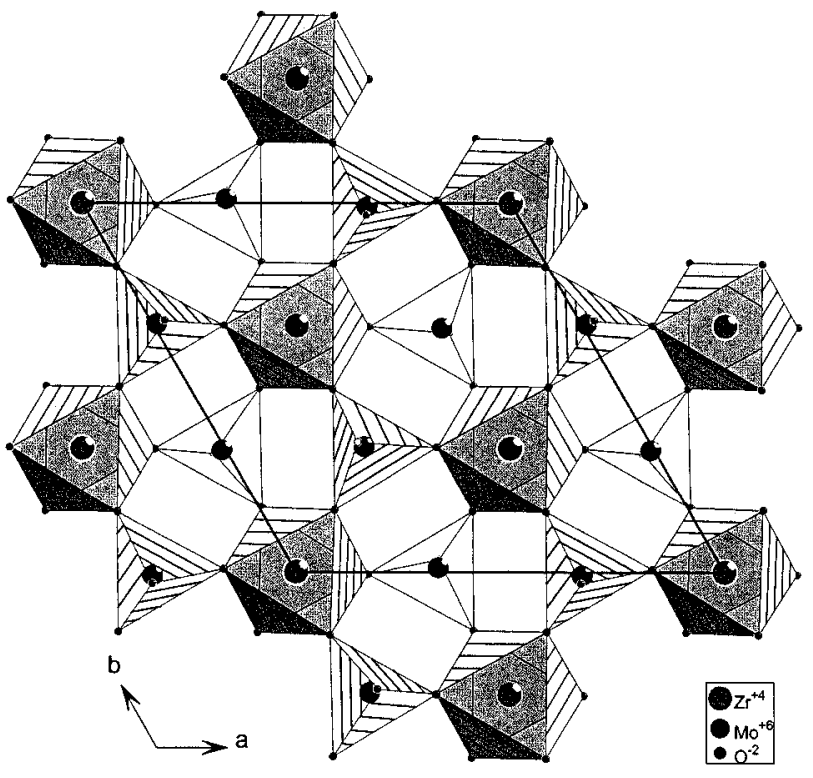

cations are present in distorted tetrahedral coordination, with one $\mathrm{O}$ atom bonded only to Mo and the other three $\mathrm{O}$ atoms shared by Mo and $\mathrm{Zr}$ atoms. This structure gives rise to two types of Mo-O distances: a shorter bond at $1.690 \AA$ and three longer bonds at $1.763,1.762$, and $1.767 \AA$, respectively. The resulting tetrahedral $\mathrm{O}=\mathrm{MoO}_{3}$ species in $\mathrm{Zr}\left(\mathrm{MoO}_{4}\right)_{2}$ have approximate $C_{3 v}$ symmetry.

For a tetrahedral $\mathrm{MX}_{4}$ species of $T_{d}$ symmetry, all four normal modes of vibration are Raman-active and the $v_{2}(\mathrm{E})$ and $v_{4}\left(\mathrm{~F}_{2}\right)$ modes are often too similar in frequency to be detected as separate bands. ${ }^{36,37}$ For tetrahedral $\mathrm{MoO}_{4}{ }^{2-}(\mathrm{aq})$, these four vibration modes, $v_{1}\left(\mathrm{~A}_{1}\right), v_{3}\left(\mathrm{~F}_{2}\right)$, and $v_{2}\left(v_{4}\right)$ are found at 897 , 837 , and $317(317) \mathrm{cm}^{-1}$, respectively. ${ }^{38}$ When the symmetry of $\mathrm{MX}_{4}$ species decreases from $T_{d}$ to $C_{3 v}$, as in the case of $\mathrm{O}=$ $\mathrm{MoO}_{3}$ in $\mathrm{Zr}\left(\mathrm{MoO}_{4}\right)_{2}$, both $v_{3}\left(\mathrm{~F}_{2}\right)$ and $v_{4}\left(\mathrm{~F}_{2}\right)$ split into two modes $\left(\mathrm{A}_{1}+\mathrm{E}\right) .{ }^{36} \mathrm{We}$ assign the $1003 \mathrm{~cm}^{-1}$ band for $\mathrm{Zr}\left(\mathrm{MoO}_{4}\right)_{2}$ to the vibration of the shorter $\mathrm{Mo}-\mathrm{O}$ bonds and the bands at 945 and $750 \mathrm{~cm}^{-1}$ to antisymmetric and symmetric $v(\mathrm{O}-\mathrm{Mo}-\mathrm{O})$ stretchings of the longer $\mathrm{Mo}-\mathrm{O}$ bonds. The bands at 328 and $361 \mathrm{~cm}^{-1}$ are assigned to the $\delta(\mathrm{Mo}-\mathrm{O})$ deformation modes and the band at $214 \mathrm{~cm}^{-1}$ to the $\rho_{\mathrm{r}}(\mathrm{Mo}-\mathrm{O})$ rocking mode. The band at $177 \mathrm{~cm}^{-1}$ appears to arise from lattice vibration modes.

These band assignments were confirmed by ${ }^{18} \mathrm{O}$ exchange studies, in which some of the lattice ${ }^{16} \mathrm{O}$ atoms in $\mathrm{Zr}\left(\mathrm{MoO}_{4}\right)_{2}$ were replaced with ${ }^{18} \mathrm{O}$. The Raman spectrum (spectra $\mathrm{c}$ in Figure $3 \mathrm{~A}$ ) for partially ${ }^{18} \mathrm{O}$-exchanged $\mathrm{Zr}\left(\mathrm{MoO}_{4}\right)_{2}$ showed new bands at 710 (weak), 730, 895 (weak), 919, and $956 \mathrm{~cm}^{-1}$. The estimated frequencies for $\mathrm{Mo}^{-18} \mathrm{O}$ stretching and ${ }^{16} \mathrm{O}-\mathrm{Mo}-$ ${ }^{18} \mathrm{O}$ symmetric and antisymmetric vibration are 954,920 , and $730 \mathrm{~cm}^{-1}$, respectively. These values were calculated by assuming that the force constants for $\mathrm{Mo}-\mathrm{O}$ bonds do not change upon ${ }^{18} \mathrm{O}$ isotopic substitution and that the vibration frequencies are inversely proportional to the square root of the reduced mass in the assumed harmonic oscillator. ${ }^{37}$ These estimates agree with the observed frequencies. Unresolved broader bands were also detected at $\sim 710$ and $\sim 895 \mathrm{~cm}^{-1}$, but their frequencies cannot be determined accurately because they overlap with stronger bands. Spectra $b$ and $c$ in Figure $3 \mathrm{~A}$ show that the intensity ratio of the antisymmetric $v(\mathrm{O}-\mathrm{Mo}-\mathrm{O})$ band $\left(945 \mathrm{~cm}^{-1}\right)$ to the $v(\mathrm{Mo}=\mathrm{O})$ band $\left(1003 \mathrm{~cm}^{-1}\right)$ decreased from 1.15 to 0.96 after ${ }^{18} \mathrm{O}$ isotopic substitution, suggesting that

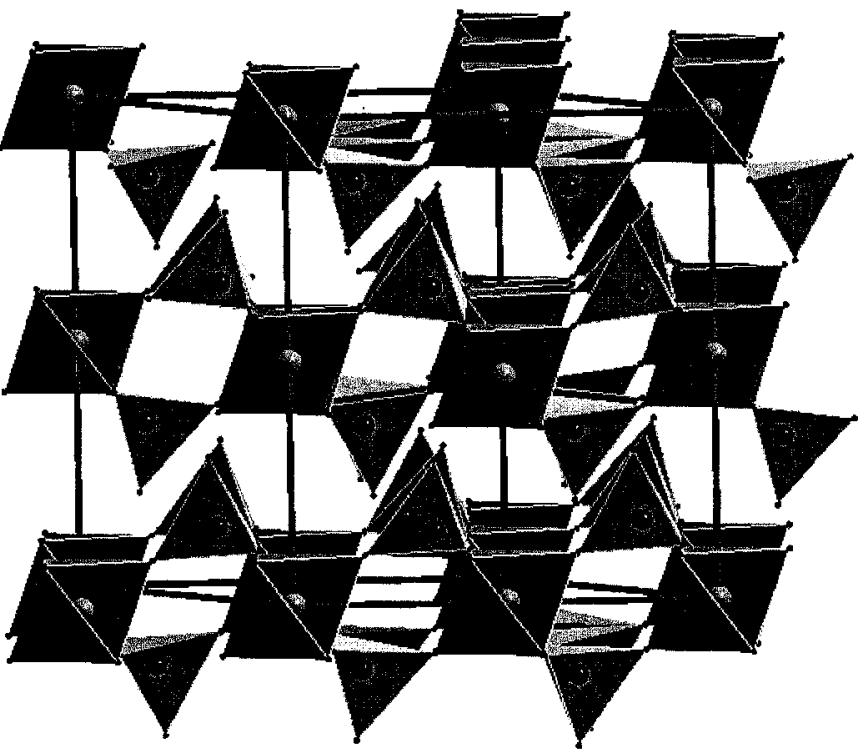

Figure 4. Crystal structure of hexagonal $\mathrm{Zr}\left(\mathrm{MoO}_{4}\right)_{2}$. The figures were drawn using structural parameters from ref 33 . 
bridging $\mathrm{O}$ atoms exchange with gas phase ${ }^{18} \mathrm{O}_{2}$ more rapidly than $\mathrm{O}$ atoms in terminal $\mathrm{Mo}=\mathrm{O}$ groups.

Solid-state reactions of crystalline $\mathrm{MoO}_{3}$ with $\mathrm{ZrO}_{2}$ were also studied by X-ray absorption spectroscopy. X-ray absorption spectra can be divided into two parts, defined in terms of the energy range and the information provided by each region. The absorption edge position and the spectral features near the edge (XANES) reflect the oxidation state and coordination symmetry of the absorber. The extended X-ray absorption fine structure (EXAFS) arises from scattering of the ejected photoelectrons by neighboring atoms and it reflects the local structure around the absorber. ${ }^{16}$ For molybdenum oxides, the Mo-K edge detected at $\sim 20 \mathrm{keV}$ corresponds to the ejection of an Mo 1s electron, while the pre-edge feature at $\sim 19.99 \mathrm{keV}$ arises from $1 \mathrm{~s}$ to $4 \mathrm{~d}$ electronic transitions that are dipole-forbidden in centrosymmetric structures. ${ }^{39}$ The $\mathrm{Mo}^{6+}$ cations in $\mathrm{MoO}_{3}$ adopt off-center positions within distorted $\mathrm{MoO}_{6}$ octahedra and this distortion allows these forbidden transitions to occur. The intensity of this pre-edge feature increases as the $\mathrm{Mo}^{6+}$ centers acquire tetrahedral symmetry, as a result of greater $\mathrm{p}-\mathrm{d}$ orbital mixing in $\mathrm{Mo}^{6+}$ tetrahedra. ${ }^{40}$

The Mo-K near-edge spectra (Figure 5A) and the radial structure functions obtained from the fine structure region (Figure 5B) for a mixture of $\mathrm{MoO}_{3}$ and $\mathrm{ZrO}_{x}(\mathrm{OH})_{4-2 x}$ after treatment at various temperatures are shown in Figure 5. Both the near-edge spectrum and the radial structure functions of the $\mathrm{MoO}_{3} / \mathrm{ZrO}_{x}(\mathrm{OH})_{4-2 x}$ physical mixture are initially similar to bulk $\mathrm{MoO}_{3}$. After this mixture was treated at $723 \mathrm{~K}$ for $3 \mathrm{~h}$, the nearedge spectrum changed significantly, but without an observable change in the intensity of the pre-edge feature. The radial structure functions remain unchanged, but the intensity of the peak corresponding to Mo-Mo neighbors (maximum at 3.17 $\AA$ ) decreased (Figure 5B). These results suggest that thermal treatment at $723 \mathrm{~K}$ led to the dispersion of bulk $\mathrm{MoO}_{3}$ onto the $\mathrm{ZrO}_{2}$ surface with a consequent decrease in $\mathrm{MoO}_{3}$ domain size, but without any reaction between $\mathrm{MoO}_{3}$ and $\mathrm{ZrO}_{2}$, which would have changed the local coordination. At $973 \mathrm{~K}$, the pre-edge feature became stronger and the scattering peak corresponding to the $\mathrm{Mo}-\mathrm{Zr}$ next nearest neighbor shell in the radial structure function also increased in intensity (curve $d$ in Figure 5A,B), reflecting the formation of bulk $\mathrm{Zr}\left(\mathrm{MoO}_{4}\right)_{2}$. The scattering peak due to the Mo-Mo shell in the radial structure functions disappeared and a new feature, corresponding to a Mo- $\mathrm{Zr}$ shell (with a maximum at $3.45 \AA$ ), became clearly visible (Figure $5 \mathrm{~B})$. The more intense pre-edge peak for $\mathrm{Zr}\left(\mathrm{MoO}_{4}\right)_{2}$ relative to that of $\mathrm{MoO}_{3}$ is consistent with the tetrahedral environment of $\mathrm{Mo}^{6+}$ ions in $\mathrm{Zr}\left(\mathrm{MoO}_{4}\right)_{2}$. For the sample treated at $873 \mathrm{~K}$ for $3 \mathrm{~h}$, both the near-edge spectrum and the radial structure function (curve $\mathrm{c}$ in Figure 5A,B) are similar to those obtained for $\mathrm{Zr}$ $\left(\mathrm{MoO}_{4}\right)_{2}$. The pre-edge peak is more intense than that for the sample treated at $723 \mathrm{~K}$ but is less intense than that for $\mathrm{Zr}$ $\left(\mathrm{MoO}_{4}\right)_{2}$. The radial structure function shows a scattering peak with a maximum at $3.37 \AA$ (curve c in Figure $5 \mathrm{~B}$ ), which lies between 3.17 and $3.45 \AA$ and which may reflect overlapping Mo-Mo and Mo-Zr scattering features. These results for the sample treated at $873 \mathrm{~K}$ show that the reaction of $\mathrm{MoO}_{3}$ and $\mathrm{ZrO}_{2}$ starts at $\sim 873 \mathrm{~K}$.

Effect of Treatment Temperature and Mo Content on $\mathrm{MoO}_{\mathbf{x}} / \mathrm{ZrO}_{2}$ Structure. The Raman spectra of supported molybdenum oxides and their structural interpretation have recently been reviewed by Mestl and Srinivasan. ${ }^{14}$ Supported molybdenum oxides can exist as $\mathrm{MoO}_{x}$ monomers, twodimensional polymolybdates, and bulk $\mathrm{MoO}_{3}$. The dependence of the structure of dispersed $\mathrm{MoO}_{x}$ on Mo concentration, $\mathrm{pH}$ of
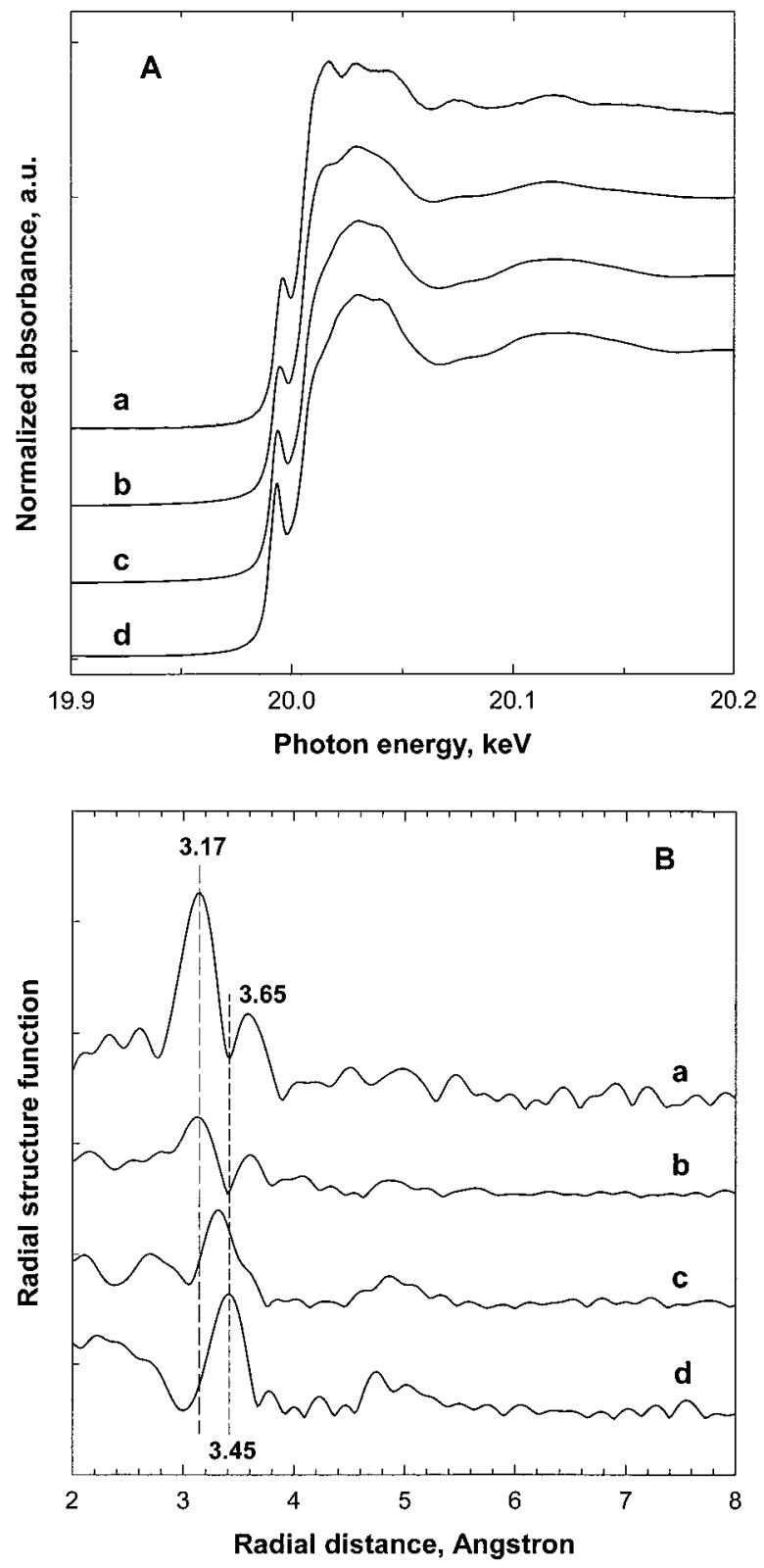

Figure 5. Near-edge $X$-ray absorption spectra (A) and radial structure function (B) of a physical mixture of $\mathrm{MoO}_{3}$ and $\mathrm{ZrO}_{x}(\mathrm{OH})_{4-2 x}(\mathrm{Mo} / \mathrm{Zr}$ atomic ratio $=2: 1$ ) after treatment in $20 \% \mathrm{O}_{2} / \mathrm{He}$ at different temperatures: (a) ambient; (b) $723 \mathrm{~K}$ for $3 \mathrm{~h}$; (c) $873 \mathrm{~K}$ for $3 \mathrm{~h}$; (d) $973 \mathrm{~K}$ for $3 \mathrm{~h}$.

impregnation solution, thermal treatment temperature, and oxide support were previously examined. ${ }^{14,41-45}$ These studies have concluded that the structure of supported $\mathrm{MoO}_{x}$ species depends strongly on the identity of the oxide support, on the Mo content, and on the treatment temperature, but only weakly on the solution $\mathrm{pH}$ and on the type of soluble Mo precursor used. Since hydration of supported $\mathrm{MoO}_{x}$ samples by exposure to ambient moisture can alter their Raman spectra, ${ }^{45-49}$ all spectra in our study were obtained after in situ treatment at the specified temperatures within the Raman cell.

The Raman spectra for $1 \mathrm{wt} \% \mathrm{MoO}_{3} / \mathrm{ZrO}_{2}$ samples treated in $20 \% \mathrm{O}_{2} / \mathrm{He}$ for $1 \mathrm{~h}$ at various temperatures are shown in Figure 6. Spectrum a shows broad bands at 168, 402, 523, 859, 940,970 , and $1086 \mathrm{~cm}^{-1}$ after treatment at $393 \mathrm{~K}$. The band at $1086 \mathrm{~cm}^{-1}$ arises from carbonate species formed on $\mathrm{ZrO}_{2}$ by reaction with ambient $\mathrm{CO}_{2}$. The Raman bands at 168, 402, and 


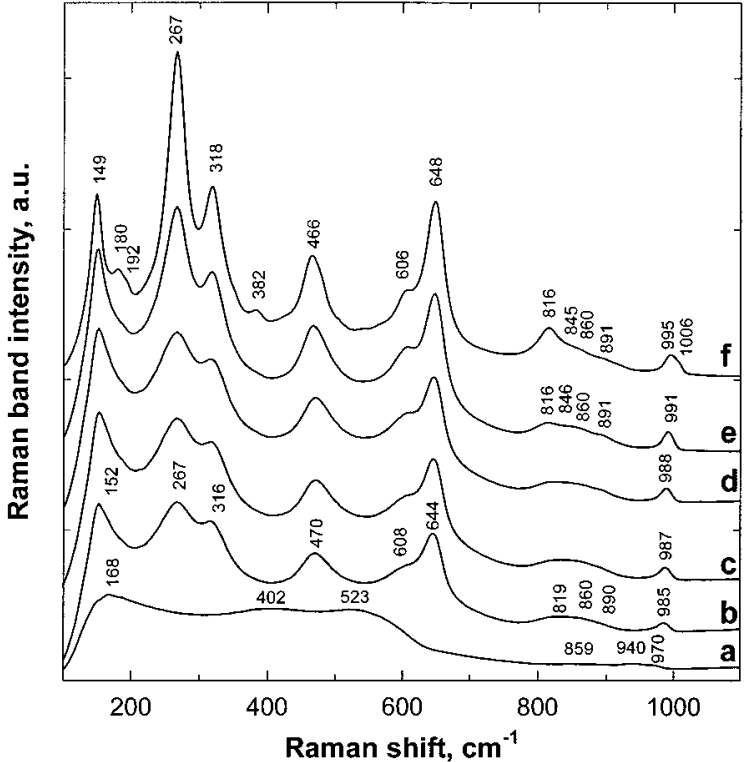

Figure 6. Raman spectra recorded at $298 \mathrm{~K}$ for 1 wt $\% \mathrm{MoO}_{x} / \mathrm{ZrO}_{2}$ sample after pretreatment in $20 \% \mathrm{O}_{2} / \mathrm{He}$ for $1 \mathrm{~h}$ at different temperatures: (a) $393 \mathrm{~K}$; (b) $673 \mathrm{~K}$; (c) $723 \mathrm{~K}$; (d) $773 \mathrm{~K}$; (e) $873 \mathrm{~K}$; (f) 973 $\mathrm{K}$.

$523 \mathrm{~cm}^{-1}$ are assigned to amorphous $\mathrm{ZrO}_{x}(\mathrm{OH})_{4-2 x}$. The bands at 940 and $970 \mathrm{~cm}^{-1}$ arise from $\mathrm{Mo}=\mathrm{O}$ stretching modes of dispersed polymolybdates and the broad band centered at 859 $\mathrm{cm}^{-1}$ is assigned to monomeric $\mathrm{MoO}_{4}$ species. ${ }^{14}$

Treatment at $673 \mathrm{~K}$ led to the appearance of a distinct band at $\sim 985 \mathrm{~cm}^{-1}$ along with overlapping broad bands in the $800-$ $900 \mathrm{~cm}^{-1}$ region. The band at $\sim 985 \mathrm{~cm}^{-1}$ is assigned to the $\mathrm{Mo}=\mathrm{O}$ stretching mode in $\mathrm{MoO}_{6}$ octahedra within twodimensional polymolybdates. This band shifts to higher frequencies with increasing treatment temperature, apparently as a result of $\mathrm{MoO}_{x}$ domain growth. An increase in $\mathrm{Mo}=\mathrm{O}$ frequencies with increasing polymolybdate cluster size has been reported previously. ${ }^{48-50}$ This finding is consistent with UV-visible data, which showed the absorption energy of the 1 wt $\% \mathrm{MoO}_{x} / \mathrm{ZrO}_{2}$ sample decreased with increasing pretreatment temperature. ${ }^{11}$ The decreasing UV-vis absorption edge energy indicates that $\mathrm{MoO}_{x}$ domains grow with increasing pretreatment temperature. ${ }^{51}$ The observed $v(\mathrm{Mo}=\mathrm{O})$ stretches at wavenumbers above 980 $\mathrm{cm}^{-1}$ suggests that two-dimensional polymolybdate species exist even in $1 \mathrm{wt} \% \mathrm{MoO}_{3}$ samples, despite their low Mo surface density $\left(<1 \mathrm{Mo} / \mathrm{nm}^{2}\right)$. Recently, Xiong et al. ${ }^{52}$ reported that octahedral polymolybdate species were detected by UV resonance Raman spectroscopy even at very low Mo contents $(0.1$ wt $\%$ ) on $\alpha-\mathrm{Al}_{2} \mathrm{O}_{3}$. The broad bands at $800-900 \mathrm{~cm}^{-1}$ become more clearly resolved after treatment at 873 or $973 \mathrm{~K}$, probably because the structure of $\mathrm{MoO}_{x}$ monomers becomes more uniform after annealing at high temperature.

At least four distinct Raman bands were detected in the 800$900 \mathrm{~cm}^{-1}$ range (at $816,845,860$, and $891 \mathrm{~cm}^{-1}$, respectively) for the sample treated at $873 \mathrm{~K}$. After treatment at $973 \mathrm{~K}$, the band at $816 \mathrm{~cm}^{-1}$ became sharper and a band at $1006 \mathrm{~cm}^{-1}$ appeared as a shoulder in the $\mathrm{Mo}=\mathrm{O}$ band at $995 \mathrm{~cm}^{-1}$. The bands at 816 and $1006 \mathrm{~cm}^{-1}$ were assigned to antisymmetric $v(\mathrm{O}-\mathrm{Mo}-\mathrm{O})$ and $v(\mathrm{Mo}=\mathrm{O})$ in a $\mathrm{MoO}_{5}$ tetragonal-pyramidal structure, $\mathrm{O}=\mathrm{Mo}(\mathrm{O}-\mathrm{Zr})_{4}$. The $v(\mathrm{Mo}=\mathrm{O})$ modes in tetragonalpyramidal $\left[\mathrm{O}=\mathrm{MoCl}_{4}\right]^{-}, 53 \mathrm{O}=\mathrm{MoF}_{4},{ }^{54,55}$ and $\mathrm{O}=\mathrm{MoCl}_{4}{ }^{56,57}$ were observed at 1008,1015 , and $1048 \mathrm{~cm}^{-1}$, respectively. Desikan et al. ${ }^{58}$ assigned the Raman band observed on $12 \mathrm{wt}$ $\% \mathrm{MoO}_{3} / \mathrm{Al}_{2} \mathrm{O}_{3}$ at $1010 \mathrm{~cm}^{-1}$ to $v(\mathrm{Mo}=\mathrm{O})$ of a monooxo $\mathrm{O}=$ $\mathrm{Mo}(\mathrm{O}-\mathrm{Al})_{4}$ species, the structure of which was proposed earlier

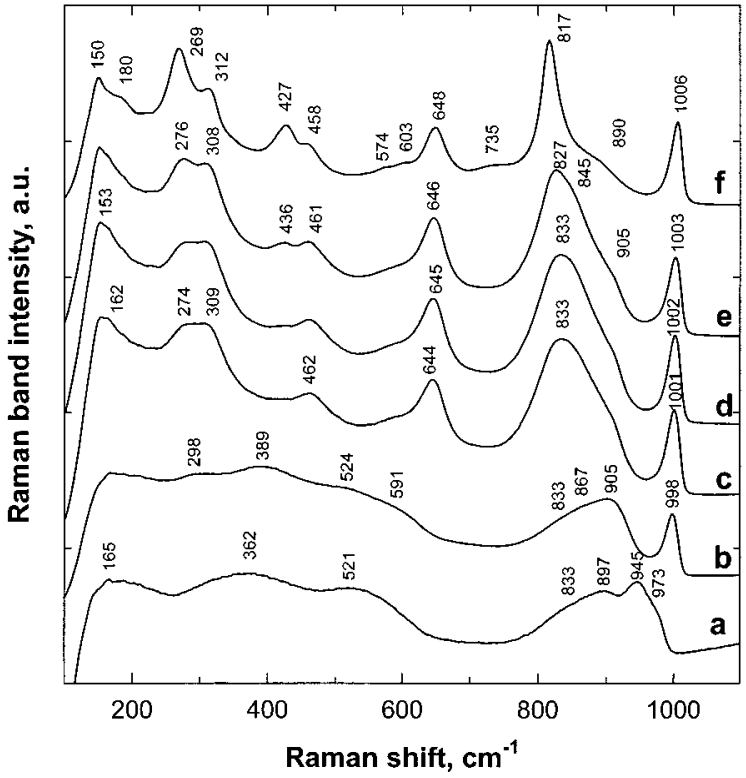

Figure 7. Raman spectra recorded at $298 \mathrm{~K}$ for $11 \mathrm{wt} \% \mathrm{MoO}_{x} / \mathrm{ZrO}_{2}$ sample after pretreatment in $20 \% \mathrm{O}_{2} / \mathrm{He}$ for $1 \mathrm{~h}$ at different temperatures: (a) $393 \mathrm{~K}$; (b) $673 \mathrm{~K}$; (c) $723 \mathrm{~K}$; (d) $773 \mathrm{~K}$; (e) $873 \mathrm{~K}$; (f) 973 $\mathrm{K}$.

by Payen et al. ${ }^{48}$ and Stencel et al. ${ }^{49}$ The bands at 891 and 845 $\mathrm{cm}^{-1}$ were assigned to the antisymmetric and symmetric $v(\mathrm{O}=$ $\mathrm{Mo}=\mathrm{O}$ ) modes in isolated $\mathrm{MoO}_{4}$ tetrahedra, by analogy with the assignments of bands at 897 and $827 \mathrm{~cm}^{-1}$ to these modes in aqueous $\mathrm{MoO}_{4}{ }^{2-}$ ions. ${ }^{38}$ The band at $860 \mathrm{~cm}^{-1}$ may arise from a less distorted $\mathrm{MoO}_{4}$ species than those for the $891 \mathrm{~cm}^{-1}$ band. The structure of the $\mathrm{ZrO}_{2}$ support in the $1 \mathrm{wt} \% \mathrm{MoO}_{3} /$ $\mathrm{ZrO}_{2}$ sample also changed with increasing temperature and tetragonal $\mathrm{ZrO}_{2}$ was detected after treatment at $673 \mathrm{~K}$ for $1 \mathrm{~h}$ by its Raman bands at 152, 267, 316, 470, 608, and $644 \mathrm{~cm}^{-1} .59$ Tetragonal $\mathrm{ZrO}_{2}$ was stable up to $873 \mathrm{~K}$. Monoclinic $\mathrm{ZrO}_{2}$ bands at 180,192 , and $382 \mathrm{~cm}^{-1}$ appeared after treatment at $973 \mathrm{~K}$ and higher temperatures. ${ }^{60}$

Mo surface densities approach polymolybdate monolayer values $\left(\sim 5 \mathrm{Mo} / \mathrm{nm}^{2}\right)$ for $11 \mathrm{wt} \% \mathrm{MoO}_{x} / \mathrm{ZrO}_{2}$ samples after treatment at temperatures above $723 \mathrm{~K}$ (Figure 1). After treatment at $393 \mathrm{~K}$, the Raman spectra for this sample showed bands at 973, 945, 897, 833 (sh), 521, and $362 \mathrm{~cm}^{-1}$ (Figure 7). The bands at 945 and $973 \mathrm{~cm}^{-1}$ were assigned to $v(\mathrm{Mo}=\mathrm{O})$ modes in $\mathrm{MoO}_{6}$ octahedra within polymolybdate domains. ${ }^{14}$ More specifically, the band at $945 \mathrm{~cm}^{-1}$ may arise from $\mathrm{Mo}_{5} \mathrm{O}_{16}{ }^{2-}$ species (see discussion below). Treatment in air at $673 \mathrm{~K}$ caused the Raman bands at 945 and $973 \mathrm{~cm}^{-1}$ to coalesce into one band at $998 \mathrm{~cm}^{-1}$, and the band at $897 \mathrm{~cm}^{-1}$ to shift to $905 \mathrm{~cm}^{-1}$. The shift of the bands at 945 and $973 \mathrm{~cm}^{-1}$ to higher frequencies reflects the dehydration of the sample at 673 $\mathrm{K}$; physisorbed $\mathrm{H}_{2} \mathrm{O}$ weakens $\mathrm{Mo}=\mathrm{O}$ bonds and it causes the $v(\mathrm{Mo}=\mathrm{O})$ in $\mathrm{MoO}_{x}$ species to shift to lower frequencies. ${ }^{45-49}$ The shift of the $897 \mathrm{~cm}^{-1}$ band to $905 \mathrm{~cm}^{-1}$ for isolated tetrahedral $\mathrm{MoO}_{4}$ species on $\mathrm{Al}_{2} \mathrm{O}_{3}$ was attributed by Jeziorowski et al. ${ }^{42}$ and Wang et al. ${ }^{44}$ to interactions with the $\mathrm{Al}_{2} \mathrm{O}_{3}$. Treatment at $723 \mathrm{~K}$ caused the $905 \mathrm{~cm}^{-1}$ band to weaken gradually and the $833 \mathrm{~cm}^{-1}$ band to become more intense until it emerged as the most intense band in the $800-900 \mathrm{~cm}^{-1}$ region (Figure $8 \mathrm{~B}, \mathrm{C})$. The $v(\mathrm{Mo}=\mathrm{O})$ frequency shifted from 998 to $1001 \mathrm{~cm}^{-1}$ and became stronger after samples were treated in air at $723 \mathrm{~K}$. The more intense bands for symmetric $v(\mathrm{Mo}-$ $\mathrm{O}-\mathrm{Mo})\left(833 \mathrm{~cm}^{-1}\right)$ and $v(\mathrm{Mo}=\mathrm{O})\left(998-1001 \mathrm{~cm}^{-1}\right)$ modes in octahedral polymolybdates became stronger at the expense of the bands for isolated $\mathrm{MoO}_{4}$ tetrahedra $[v(\mathrm{O}=\mathrm{Mo}=\mathrm{O})$ at 

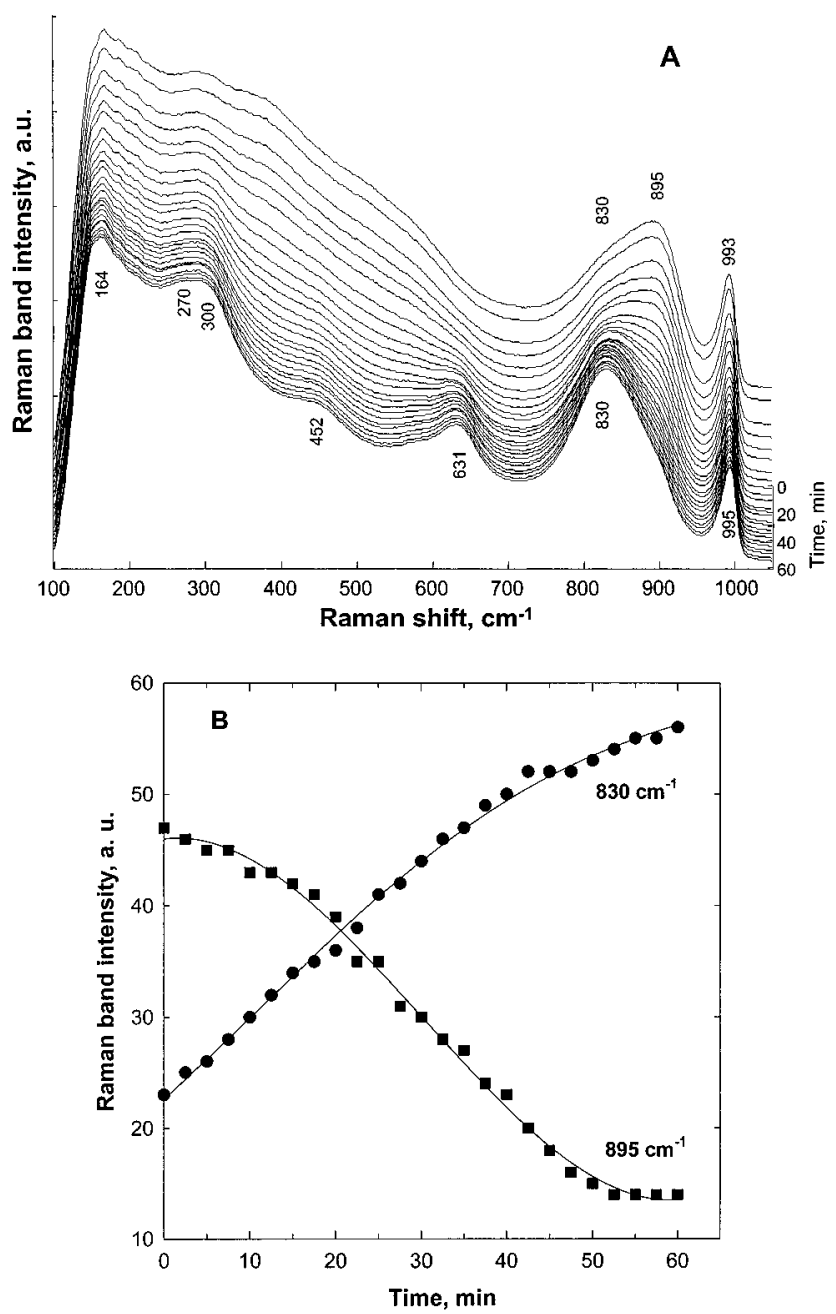

Figure 8. Raman spectra recorded at $723 \mathrm{~K}$ in $20 \% \mathrm{O}_{2} / \mathrm{He}$ for $11 \mathrm{wt}$ $\% \mathrm{MoO}_{x} / \mathrm{ZrO}_{2}$ sample after temperature was increased from $673 \mathrm{~K}$ (A) and intensities of Raman bands at 830 and $895 \mathrm{~cm}^{-1}$ as a function of time (B). The time axis represents the time length for the sample to stay at $723 \mathrm{~K}$ after the temperature was increased rapidly from $673 \mathrm{~K}$.

$\left.\sim 905 \mathrm{~cm}^{-1}\right]$. These data suggest that isolated $\mathrm{MoO}_{4}$ tetrahedra condense to form octahedral polymolybdate domains by forming bridged $\mathrm{Mo}-\mathrm{O}-\mathrm{Mo}$ bonds as the surface area of the $\mathrm{ZrO}_{2}$ support decreases with increasing treatment temperature.

The Raman spectra for $11 \mathrm{wt} \% \mathrm{MoO}_{x} / \mathrm{ZrO}_{2}$ samples treated at 773 and $873 \mathrm{~K}$ resemble those for samples treated at $723 \mathrm{~K}$ (Figure 7), but the frequency of the $\mathrm{Mo}=\mathrm{O}$ stretching band at $1001 \mathrm{~cm}^{-1}$ was slightly shifted to 1002 and $1003 \mathrm{~cm}^{-1}$. An intense band appeared at $817 \mathrm{~cm}^{-1}$ after treatment of $973 \mathrm{~K}$ along with a new band at $1006 \mathrm{~cm}^{-1}$. These two new bands reflect the formation of tetragonal-pyramidal $\mathrm{O}=\mathrm{MoO}_{4}$ species (see discussion above). The weakening of the $833 \mathrm{~cm}^{-1}$ band after treatment at $973 \mathrm{~K}$ suggests the formation of tetragonalpyramidal $\mathrm{O}=\mathrm{MoO}_{4}$ species via dissociation of $\mathrm{Mo}-\mathrm{O}-\mathrm{Mo}$ bonds in polymolybdate species.

For samples with low Mo concentrations (11 wt \%), neither Raman spectroscopy nor X-ray diffraction detected bulk $\mathrm{MoO}_{3}$ or $\mathrm{Zr}\left(\mathrm{MoO}_{4}\right)_{2}$ structures because the $\mathrm{MoO}_{x}$ surface density of these samples remained well below the monolayer value of $\sim 5$ $\mathrm{Mo} / \mathrm{nm}^{2}$ at all treatment temperatures. Bulk $\mathrm{MoO}_{3}$ is expected to form in samples with higher $\mathrm{MoO}_{x}$ surface densities; this was detected by Raman in the 20.7 wt $\% \mathrm{MoO}_{x} / \mathrm{ZrO}_{2}$ sample (Figure 9). The Raman bands detected at 752 and $821 \mathrm{~cm}^{-1}$ after treatment at 723 or $773 \mathrm{~K}$ arise from crystalline $\mathrm{Zr}\left(\mathrm{MoO}_{4}\right)_{2}$ and $\mathrm{MoO}_{3}$, respectively. The band at $917 \mathrm{~cm}^{-1}$ appears to

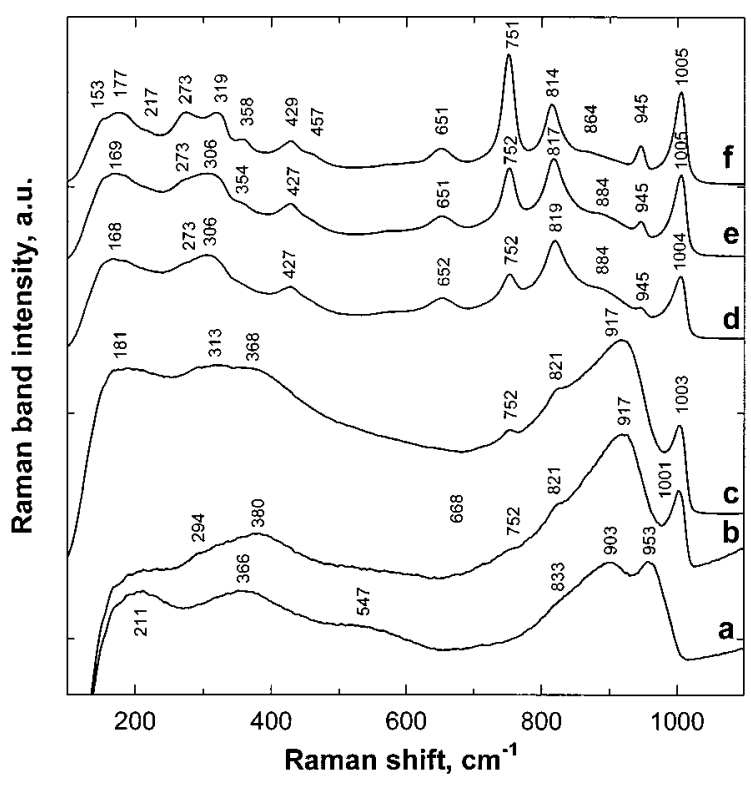

Figure 9. Raman spectra recorded at $298 \mathrm{~K}$ for $20.7 \mathrm{wt} \% \mathrm{MoO}_{x}$ / $\mathrm{ZrO}_{2}$ sample after pretreatment in $20 \% \mathrm{O}_{2}$ for $1 \mathrm{~h}$ at different temperatures: (a) $393 \mathrm{~K}$; (b) $723 \mathrm{~K}$; (c) $773 \mathrm{~K}$; (d) $823 \mathrm{~K}$; (e) $873 \mathrm{~K}$; (f) $973 \mathrm{~K}$.

correspond to the symmetric $v(\mathrm{O}=\mathrm{Mo}=\mathrm{O})$ modes in highly distorted $\mathrm{MoO}_{4}$ tetrahedra; ${ }^{42}$ it disappeared after treatment at temperatures above $\sim 823 \mathrm{~K}$, suggesting that tetrahedral $\mathrm{MoO}_{4}$ species oligomerize upon heating. The $v(\mathrm{Mo}=\mathrm{O})$ bands appeared above $1000 \mathrm{~cm}^{-1}$ and they shifted to higher wavenumbers with increasing treatment temperature. A new band at $\sim 651$ $\mathrm{cm}^{-1}$ emerged in samples treated above $823 \mathrm{~K}$; it can be assigned to the symmetric $v(\mathrm{Mo}-\mathrm{O}-\mathrm{Zr})$ mode in $\mathrm{O}=\mathrm{MO}_{4}$ tetragonal-pyramidal structures, by analogy with the assignment of $668 \mathrm{~cm}^{-1}$ to symmetric $\mathrm{Mo}-\mathrm{O}-\mathrm{Mo}$ stretching in $\mathrm{MoO}_{3}$. The bands at 752 and $945 \mathrm{~cm}^{-1}$ became more intense with increasing treatment temperature, as expected from the gradual formation of crystalline $\mathrm{Zr}\left(\mathrm{MoO}_{4}\right)_{2}$ as the treatment temperature increased.

Raman spectra for the 37 wt $\% \mathrm{MoO}_{x} / \mathrm{ZrO}_{2}$ sample are shown in Figure 10. After treatment at $393 \mathrm{~K}$, Raman bands were detected at 211, 343, 378 (sh), 447 (w), 601 (w), 663 (w), 692 (w), $756(\mathrm{w}), 842,885,927$ (sh), 950, and 970(sh) $\mathrm{cm}^{-1}$. This spectrum resembles that for ammonium pentamolybdate (spectrum a in Figure 10; $\left.\left(\mathrm{NH}_{4}\right)_{4} \mathrm{Mo}_{5} \mathrm{O}_{17} \cdot 2 \mathrm{H}_{2} \mathrm{O}\right)$, which is a product of AHM decomposition at $373 \mathrm{~K}^{61,62}$ The structure and chemical composition of this pentamolybdate species derived from AHM thermal decomposition was verified using X-ray diffraction and thermogravimetry. ${ }^{62} \mathrm{MoO}_{x}$ species exist predominantly as two-dimensional oligomeric domains after treatment at $393 \mathrm{~K}$. Crystalline $\mathrm{MoO}_{3}$ Raman bands appear at 200, 219, 246, 288, 339, 379, 668, 821, and $998 \mathrm{~cm}^{-1}$ (Figure 9) after treatment at 723 or $773 \mathrm{~K}$. The presence of bands at $\sim 750$ and $945 \mathrm{~cm}^{-1}$ shows that bulk $\mathrm{Zr}\left(\mathrm{MoO}_{4}\right)_{2}$ coexists as a minority species with bulk $\mathrm{MoO}_{3}$ in these samples. $\mathrm{Zr}\left(\mathrm{MoO}_{4}\right)_{2}$ bands become more intense with increasing treatment temperature at the expense of weaker $\mathrm{MoO}_{3}$ bands, suggesting that $\mathrm{Zr}\left(\mathrm{MoO}_{4}\right)_{2}$ forms via reaction of $\mathrm{MoO}_{3}$ crystallites with $\mathrm{ZrO}_{2}$, as discussed earlier. Zirconium molybdate became the predominant species after treatment at 873 or $973 \mathrm{~K}$; its characteristic Raman bands at $177,328,360,750,945$, and $1004 \mathrm{~cm}^{-1}$ increased in intensity and the bands for bulk $\mathrm{MoO}_{3}$ disappeared in the spectrum for the sample treated at $973 \mathrm{~K}$. The weak bands at 651 and 814 $\mathrm{cm}^{-1}$ remained even after treatment at $973 \mathrm{~K}$, suggesting the residual presence of $\mathrm{O}=\mathrm{MO}_{4}$ tetragonal-pyramidal species. The 


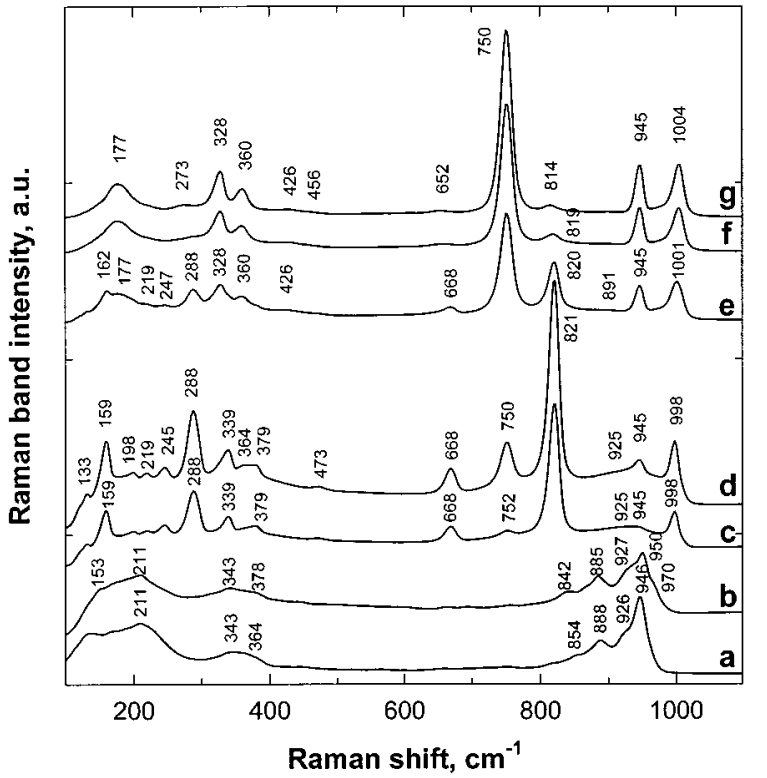

Figure 10. Raman spectra recorded at $298 \mathrm{~K}$ for $37 \mathrm{wt} \% \mathrm{MoO}_{x} / \mathrm{ZrO}_{2}$ sample after pretreatment in $20 \% \mathrm{O}_{2}$ for $1 \mathrm{~h}$ at different temperatures: (b) $393 \mathrm{~K}$; (c) $723 \mathrm{~K}$; (d) $773 \mathrm{~K}$; (e) $823 \mathrm{~K}$; (f) $873 \mathrm{~K}$; (g) 973 K. (a) Spectrum of $\mathrm{Mo}_{5} \mathrm{O}_{17}{ }^{4-}$, which was formed by decomposing $\left(\mathrm{NH}_{4}\right)_{7-}$ $\mathrm{Mo}_{7} \mathrm{O}_{24} \cdot 4 \mathrm{H}_{2} \mathrm{O}$ at $373 \mathrm{~K}$ for $1 \mathrm{~h}$.

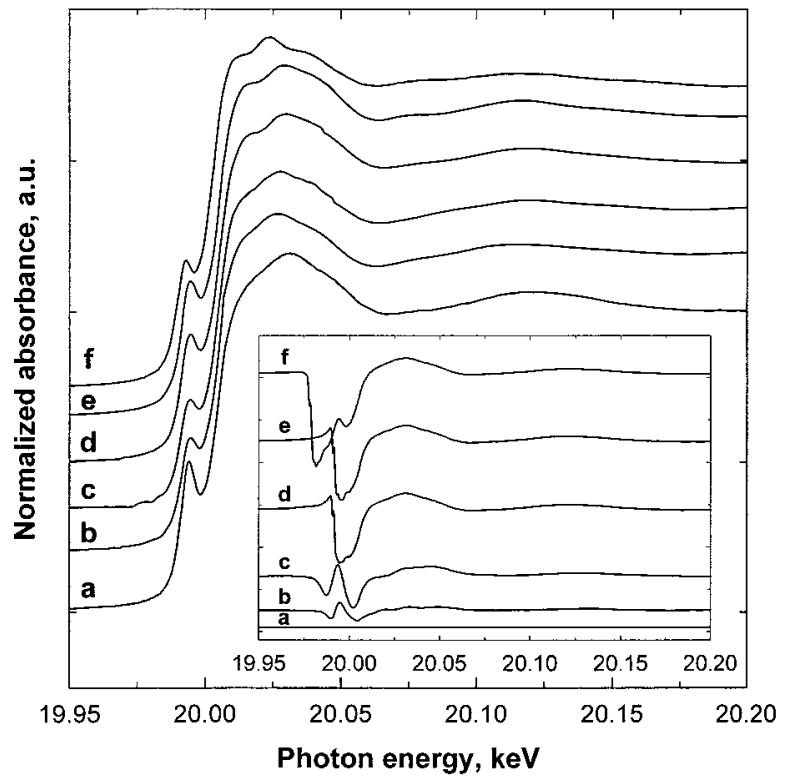

Figure 11. Near-edge $\mathrm{X}$-ray absorption spectra of $\mathrm{MoO}_{x} / \mathrm{ZrO}_{2}$ samples and standard compounds: (a) ammonium bimolybdate $\left(\left(\mathrm{NH}_{4}\right)_{2} \mathrm{Mo}_{2} \mathrm{O}_{7}\right)$; (b) $5.7 \mathrm{wt} \% \mathrm{MoO}_{x} / \mathrm{ZrO}_{2}$; (c) $11 \mathrm{wt} \% \mathrm{MoO}_{x} / \mathrm{ZrO}_{2}$; (d) $37 \mathrm{wt} \% \mathrm{MoO}_{x} /$ $\mathrm{ZrO}_{2}$; (e) 44 wt $\% \mathrm{MoO}_{x} / \mathrm{ZrO}_{2}$; (f) ammonium heptamolybdate $\left(\left(\mathrm{NH}_{4}\right)_{7^{-}}\right.$ $\mathrm{Mo}_{7} \mathrm{O}_{24} \cdot 4 \mathrm{H}_{2} \mathrm{O}$ ). The inset shows the difference spectra for each sample relative to the ammonium bimolybdate spectrum.

Raman spectra obtained for 29.7 and 44 wt $\% \mathrm{MoO}_{x} / \mathrm{ZrO}_{2}$ at a given treatment temperature and the conclusions reached from them are essentially the same as those for the $37 \mathrm{wt} \% \mathrm{MoO}_{x} /$ $\mathrm{ZrO}_{2}$ samples; therefore, their Raman spectra are not shown.

Changes in $\mathrm{MoO}_{x}$ structure with changes in $\mathrm{MoO}_{3}$ concentration and treatment temperature were also studied using X-ray absorption spectroscopy. Figure 11 shows the near-edge spectra of $\mathrm{MoO}_{x} / \mathrm{ZrO}_{2}$ with different $\mathrm{MoO}_{3}$ concentrations treated at $723 \mathrm{~K}$ and also the spectra for two model compounds [ammonium bimolybdate (ABM) and ammonium heptamolybdate (AHM)]. The difference spectra for each sample relative to the ABM spectrum are shown in the inset of Figure 11. Near-edge

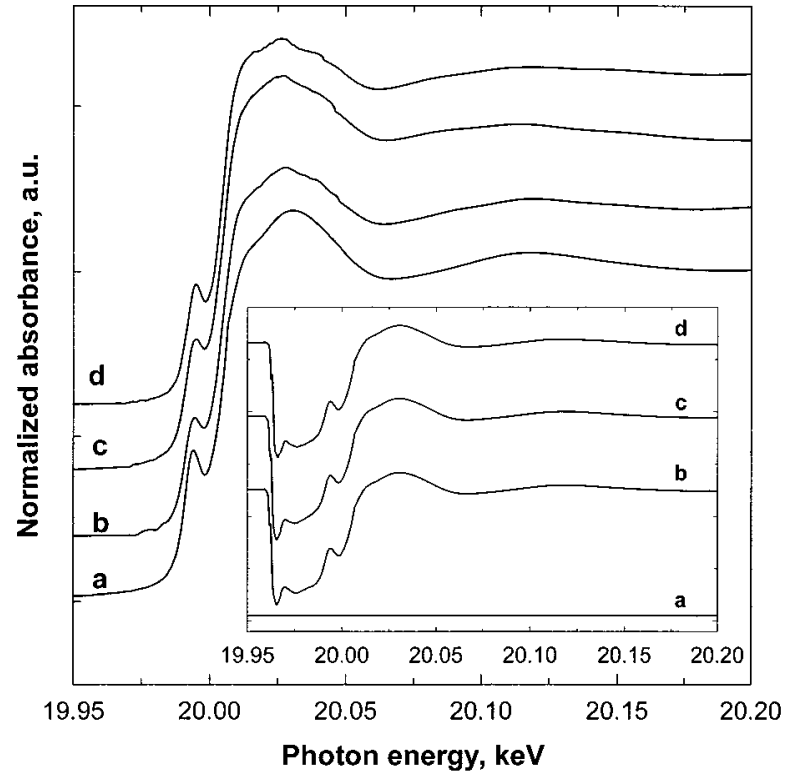

Figure 12. Near-edge $\mathrm{X}$-ray absorption spectra of 11 wt $\% \mathrm{MoO}_{x} l$ $\mathrm{ZrO}_{2}$ samples treated at different temperatures: (a) $393 \mathrm{~K}$; (b) $723 \mathrm{~K}$; (c) $873 \mathrm{~K}$; (d) $973 \mathrm{~K}$. The inset shows the difference spectra for each sample relative to the spectrum of the $393 \mathrm{~K}$ treated sample.

X-ray absorption spectra can be used to probe changes in local structure and electronic properties by comparing them with the near edge features in relevant reference compounds. ${ }^{63-65}$ For $\mathrm{MoO}_{x} / \mathrm{ZrO}_{2}$ samples with Mo surface densities below monolayer coverage $\left(\sim 5 \mathrm{Mo} / \mathrm{nm}^{2}\right)$, the near-edge spectra (curves $b$ and $c$ in Figure 11) resemble more closely the spectrum of ABM than that of AHM (insert in Figure 11). As the $\mathrm{MoO}_{3}$ concentration increased from $11 \mathrm{wt} \%$ to 37 and $44 \mathrm{wt} \%$, the near-edge spectra (curves d and e in Figure 11) gradually became similar to that for AHM (curve f), suggesting that $\mathrm{MoO}_{x}$ domains increase in size as the $\mathrm{MoO}_{3}$ concentration increases.

The near-edge spectra of $11 \mathrm{wt} \% \mathrm{MoO}_{x} / \mathrm{ZrO}_{2}$ samples treated at several temperatures $(393,723,873$, and $973 \mathrm{~K})$ are shown in Figure 12, and the difference spectra for each sample relative to that for the sample treated at $393 \mathrm{~K}$ are also shown in the inset of Figure 12. The spectrum for the sample treated at 393 $\mathrm{K}$ shows a more intense pre-edge feature than the other samples, reflecting a higher fraction of tetrahedral $\mathrm{Mo}^{6+}$ species than in the samples treated at higher temperatures. This observation is consistent with the Raman spectra shown in Figure 7 (spectrum a vs spectra c, e, and f). The pre-edge feature becomes slightly more intense with increasing treatment temperature for samples treated at 723,873 , and $973 \mathrm{~K}$; this reflects the conversion of $\mathrm{MoO}_{x}$ octahedral species to less symmetrical tetragonalpyramidal $\mathrm{MoO}_{x}$ structures.

In summary, isolated tetrahedral $\mathrm{MoO}_{4}$, two-dimensional polymolybdates, tetragonal-pyramidal $\mathrm{O}=\mathrm{MoO}_{4}$, crystalline $\mathrm{MoO}_{3}$, and $\mathrm{Zr}\left(\mathrm{MoO}_{4}\right)_{2}$ were detected by Raman spectroscopy in $\mathrm{MoO}_{x} / \mathrm{ZrO}_{2}$ samples with $1-44$ wt $\% \mathrm{MoO}_{3}(0.35-50 \mathrm{Mo} /$ $\mathrm{nm}^{2}$ ) after treatment in $20 \% \mathrm{O}_{2} / \mathrm{He}$ at $393-973 \mathrm{~K}$. $\mathrm{MoO}_{x}$ species present on $\mathrm{ZrO}_{2}$ at low and high Mo surface densities differ markedly; a distinct transition between molybdate oligomers and bulk $\mathrm{MoO}_{3}$ crystallites occurs at Mo surface densities of $\sim 5 \mathrm{Mo} / \mathrm{nm}^{2}$. At lower surface densities $\left(<5 \mathrm{Mo} / \mathrm{nm}^{2}\right)$, only twodimensional $\mathrm{MoO}_{x}$ oligomers are detected by Raman spectroscopy, without any evidence for bands corresponding to threedimensional $\mathrm{MoO}_{3}$ clusters $\left(821 \mathrm{~cm}^{-1}\right)$ or $\mathrm{Zr}\left(\mathrm{MoO}_{4}\right)_{2}(751$ $\mathrm{cm}^{-1}$ ). Raman bands at 751 and $821 \mathrm{~cm}^{-1}$ were only observed as $\mathrm{MoO}_{3}$ crystallites at Mo surface densities of $5 \mathrm{Mo} / \mathrm{nm}^{2}$ or 


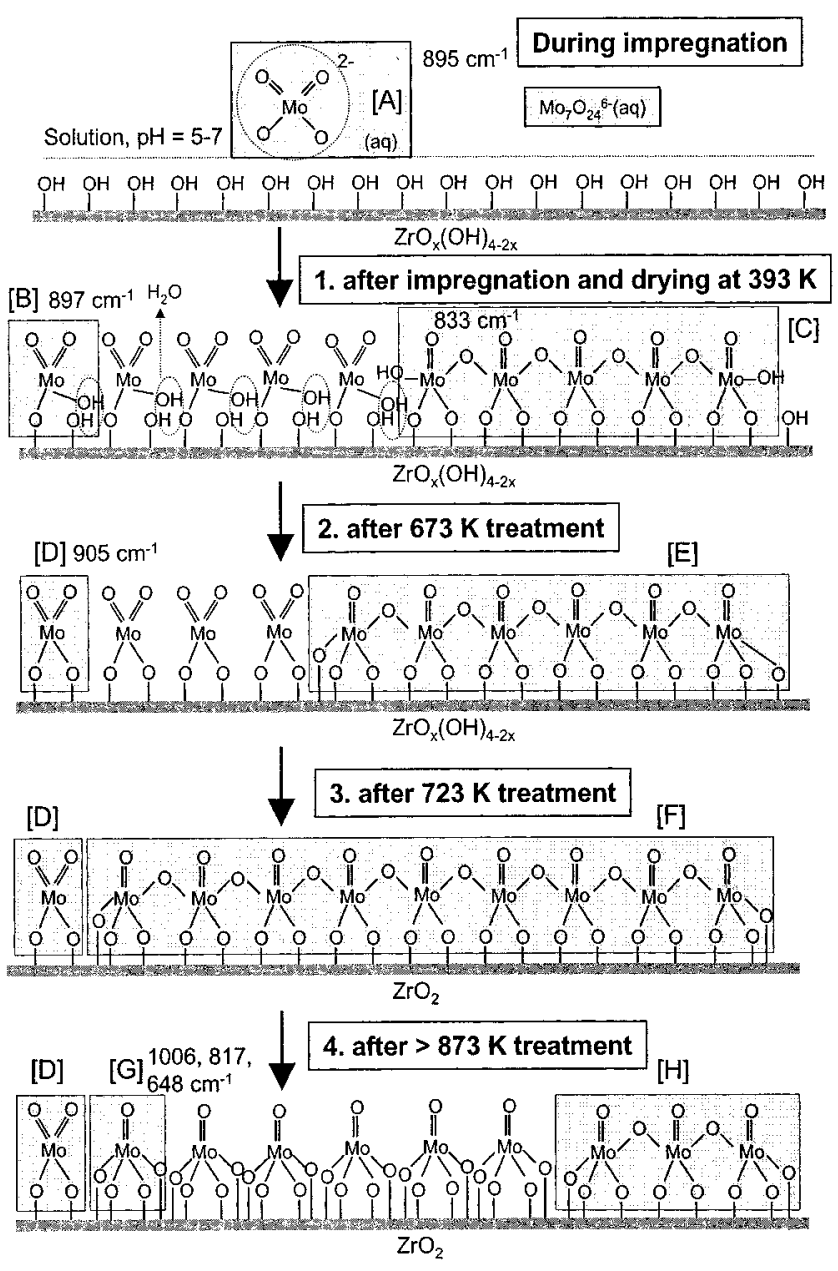

Figure 13. $\mathrm{MoO}_{x}$ structure evolution of $\mathrm{MoO}_{x} / \mathrm{ZrO}_{2}$ samples with $\mathrm{Mo}$ surface density $<5 \mathrm{Mo} / \mathrm{nm}^{2}$.

higher; they react with $\mathrm{ZrO}_{2}$ at temperatures above $873 \mathrm{~K}$ but remain as $\mathrm{MoO}_{3}$ crystallites at lower temperatures.

The treatment temperature also plays an important role in determining the structure of $\mathrm{MoO}_{x} / \mathrm{ZrO}_{2}$ catalysts. Two samples, 11 and 37 wt $\% \mathrm{MoO}_{3} / \mathrm{ZrO}_{2}$, for which Mo surface densities are below and above the monolayer coverage, respectively, are used to illustrate the structure evolution as the conditions of the thermal treatment are changed (Figure 13). The Raman spectrum for aqueous AHM solution at a $\mathrm{pH}$ of 6 showed that both isolated $\mathrm{MoO}_{4}{ }^{2-}$ (species [A] in Figure 13) and $\mathrm{Mo}_{7} \mathrm{O}_{24}{ }^{6-}$ ions coexist in solution, and they show their characteristic bands at 895 and $934 \mathrm{~cm}^{-1}$, respectively (spectra not shown). These two types of $\mathrm{MoO}_{x}$ species were preserved after the initial impregnation of $\mathrm{ZrO}_{x}(\mathrm{OH})_{4-2 x}$ with this solution and drying at room temperature. After drying at $393 \mathrm{~K}$, the 11 wt $\% \mathrm{MoO}_{x}$ l $\mathrm{ZrO}_{2}$ sample contained only isolated $\mathrm{MoO}_{4}$ tetrahedra (species [B] in Figure 13) and two-dimensional molybdate oligomers with five or more Mo atoms (species [C] in Figure 13), as shown by the presence of Raman bands at $897 \mathrm{~cm}^{-1}$ and at 945 and $973 \mathrm{~cm}^{-1}$ (spectrum a in Figure 7). After treatment at $673 \mathrm{~K}$, species [B] were anchored to the $\mathrm{ZrO}_{2}$ surface via two $\mathrm{Mo}-$ $\mathrm{O}-\mathrm{Zr}$ linkages to form tetrahedral monomolybdate species ([D] in Figure 13), giving rise to the band at $905 \mathrm{~cm}^{-1}$ (spectrum b in Figure 7). Species [D] adopted a more distorted tetrahedral structure than species [B]; this distortion may be responsible for the observed shift of the $897 \mathrm{~cm}^{-1}$ band to $905 \mathrm{~cm}^{-1}$ after treatment air at $673 \mathrm{~K}$ (spectra $\mathrm{a}$ and $\mathrm{b}$ in Figure 7). ${ }^{42}$ This treatment did not appear to increase the size of $\mathrm{MoO}_{x}$ domains, because the $833 \mathrm{~cm}^{-1}$ band for $\mathrm{Mo}-\mathrm{O}-\mathrm{Mo}$ did not change in intensity or frequency after treatment at $673 \mathrm{~K}$ (Figure 7). The bands at 945 and $973 \mathrm{~cm}^{-1}$ shifted to $998 \mathrm{~cm}^{-1}$ after treatment at $673 \mathrm{~K}$, apparently as a result of dehydration. When the sample was cooled to $298 \mathrm{~K}$ after treatment at $673 \mathrm{~K}$ and then exposed to $3.0 \mathrm{kPa} \mathrm{H}_{2} \mathrm{O}$, the spectrum a in Figure 7 was restored. The presence of physically adsorbed or weakly chemisorbed $\mathrm{H}_{2} \mathrm{O}$ or a higher concentrations of surface hydroxyl species may lead to weaker $\mathrm{Mo}=\mathrm{O}$ bonds and to a shift in the $\mathrm{Mo}=\mathrm{O}$ frequencies to lower wavenumbers. ${ }^{45,48,49}$

The amorphous zirconia support in the $11 \mathrm{wt} \% \mathrm{MoO}_{x}$ sample also underwent structural changes upon treatment at high temperature; it crystallized into its tetragonal crystal structure at $723 \mathrm{~K}$ and the surface area concurrently decreased. ${ }^{11}$ The presence of tetragonal $\mathrm{ZrO}_{2}$ was confirmed by X-ray diffraction and Raman spectroscopy (Figure $2 \mathrm{C}$ and spectrum $\mathrm{c}$ in Figure 7). The distance among isolated surface $\mathrm{MoO}_{x}$ species decreases as the $\mathrm{ZrO}_{2}$ surface area decreases and the isolated $\mathrm{MoO}_{x}$ must restructure to form $\mathrm{MoO}_{x}$ oligomers with $\mathrm{Mo}-\mathrm{O}-\mathrm{Mo}$ bonds. Oligomerization of $\mathrm{MoO}_{x}$ was first detected at $723 \mathrm{~K}$ in the 11 wt $\% \mathrm{MoO}_{x} / \mathrm{ZrO}_{2}$ sample, suggested by the increase in the intensity of the Raman band for bridging $\mathrm{Mo}-\mathrm{O}-\mathrm{Mo}$ stretching at $833 \mathrm{~cm}^{-1}$ (Figure 8A,B). The concurrent decrease in the intensity of the $905 \mathrm{~cm}^{-1}$ band suggests that domain growth occurs at the expense of isolated $\mathrm{MoO}_{4}$ tetrahedral species.

Oligomeric $\mathrm{MoO}_{x}$ species were stable at temperatures below $873 \mathrm{~K}$ in the 11 wt $\% \mathrm{MoO}_{x} / \mathrm{ZrO}_{2}$ sample; the Raman spectra after treatment at 773 or $873 \mathrm{~K}$ resembled that obtained after treatment at $723 \mathrm{~K}$. Significant structural changes occurred at $973 \mathrm{~K}$, as illustrated in Figure 13 (step 4). Bridging $\mathrm{Mo}-\mathrm{O}-$ $\mathrm{Zr}$ bonds $\left(817 \mathrm{~cm}^{-1}\right)$ were formed at the expense of $\mathrm{Mo}-\mathrm{O}-$ Mo bonds $\left(833 \mathrm{~cm}^{-1}\right)$ in octahedral polymolybdates (spectra e and $\mathrm{f}$ in Figure 7). The resulting species [G] in Figure 13 can adopt a tetragonal-pyramidal structure, which gives arise to Raman bands at 817 and $1006 \mathrm{~cm}^{-1}$ (assigned to a $\mathrm{Mo}-\mathrm{O}-\mathrm{Zr}$ antisymmetric stretching mode and a $v(\mathrm{Mo}=\mathrm{O})$ vibration mode, respectively). The antisymmetric nature of the $1006 \mathrm{~cm}^{-1}$ band suggests that an unresolved additional band may be present at its low wavenumber side; this unresolved band appears to reflect the $v(\mathrm{Mo}=\mathrm{O})$ band in the remaining unreacted polymolybdates. These observations, and the broader band on the high wavenumber side of the sharper $817 \mathrm{~cm}^{-1}$ band, suggest that some polymolybdate domains remain even after treatment at $973 \mathrm{~K}$. The Raman bands at $1001-1003 \mathrm{~cm}^{-1}$ detected after treatment at $723-873 \mathrm{~K}$ (Figure 7 ) may reflect overlapping $v(\mathrm{Mo}=\mathrm{O})$ bands in polymolybdates $\left(998 \mathrm{~cm}^{-1}\right)$ and in isolated tetragonalpyramidal $\mathrm{MoO}_{x}$ species $\left(1006 \mathrm{~cm}^{-1}\right)$. The shift of this composite band to higher frequencies with increasing treatment temperature may then reflect the increasing abundance of the tetragonal-pyramidal species [G].

$\mathrm{MoO}_{x}$ species formed at high temperatures $(>673 \mathrm{~K})$ differ markedly in samples with low and high surface density. The predominant $\mathrm{MoO}_{x}$ species in $37 \mathrm{wt} \% \mathrm{MoO}_{3} / \mathrm{ZrO}_{2}$ after drying at $393 \mathrm{~K}$ resembles a pentamolybdate structure with Raman bands at 950, 927, and $885 \mathrm{~cm}^{-1}$ (Figure 10). The formation of pentamolybdate by decomposition of heptamolybdate at $393 \mathrm{~K}$ was confirmed by independent studies of the thermal decomposition of bulk ammonium heptamolybdate. ${ }^{61,62}$ Both $\mathrm{MoO}_{3}$ and $\mathrm{Zr}\left(\mathrm{MoO}_{4}\right)_{2}$ formed after treatment at $723 \mathrm{~K}$, as shown by Raman and X-ray diffraction data. The presence of crystalline $\mathrm{MoO}_{3}$ is evident from its strong Raman bands at 821 and 998 $\mathrm{cm}^{-1}$ and the presence of $\mathrm{Zr}\left(\mathrm{MoO}_{4}\right)_{2}$ form its Raman bands at 750 and $945 \mathrm{~cm}^{-1}$ (Figure 10). For samples treated below 873 $\mathrm{K}, \mathrm{MoO}_{3}$ was the most abundant species and $\mathrm{Zr}\left(\mathrm{MoO}_{4}\right)_{2}$ was a minor component. Crystalline $\mathrm{MoO}_{3}$ was not detected in the 
37 wt $\% \mathrm{MoO}_{x} / \mathrm{ZrO}_{2}$ sample after treatment at $873 \mathrm{~K}$ for $1 \mathrm{~h}$ and the predominant bulk $\mathrm{Zr}\left(\mathrm{MoO}_{4}\right)_{2}$ species coexisted with a small residual amount of tetragonal-pyramidal $\mathrm{O}=\mathrm{MoO}_{4}$. The residual presence of tetragonal-pyramidal $\mathrm{O}=\mathrm{MoO}_{4}$ in the 973 $\mathrm{K}$ treated sample is consistent with the presence of weak bands at 652 and $814 \mathrm{~cm}^{-1}$ (spectrum $\mathrm{g}$ in Figure 10), which can be assigned to its symmetric and antisymmetric $v(\mathrm{O}-\mathrm{Mo}-\mathrm{O})$ modes, respectively.

\section{Conclusions}

Isolated tetrahedral $\mathrm{MoO}_{4}$, two-dimensional polymolybdates, tetragonal-pyramidal $\mathrm{O}=\mathrm{MoO}_{4}$, and crystalline $\mathrm{MoO}_{3}$ and $\mathrm{Zr}$ $\left(\mathrm{MoO}_{4}\right)_{2}$ species were detected by Raman and X-ray absorption spectroscopies and by X-ray diffraction in $\mathrm{MoO}_{x} / \mathrm{ZrO}_{2}$ samples with $1-44$ wt $\% \mathrm{MoO}_{3}$ after treatment in air at 393-973 K. The Mo surface density range in these samples ranged from 0.35 to $50 \mathrm{Mo} / \mathrm{nm}^{2}$. For Mo surface densities below the polymolybdate monolayer values $\left(\sim 5 \mathrm{Mo} / \mathrm{nm}^{2}\right)$, no crystalline $\mathrm{MoO}_{3}$ or $\mathrm{Zr}\left(\mathrm{MoO}_{4}\right)_{2}$ were detected by these methods after thermal treatment at 393-973 K. The size of these twodimensional polymolybdate domains increased with increasing Mo surface density; this process led to a shift in the $v(\mathrm{Mo}=\mathrm{O})$ Raman band, to changes in the near-edge X-ray absorption spectra, and to a decrease in the UV-visible edge energy with increasing surface density. Domain growth occurred via oligomerization of isolated tetrahedral $\mathrm{MoO}_{x}$ as thermal treatments decreased the $\mathrm{ZrO}_{2}$ surface area available to disperse the $\mathrm{MoO}_{x}$ species. This formation of $\mathrm{Mo}-\mathrm{O}-\mathrm{Mo}$ linkages was reversed at higher temperatures $(973 \mathrm{~K})$, which led to the dissociation on $\mathrm{Mo}-\mathrm{O}-\mathrm{Mo}$ bonds in polymolybdates and to the formation of tetragonal-pyramidal $\mathrm{O}=\mathrm{MoO}_{4}$ species. Crystalline $\mathrm{MoO}_{3}$ and $\mathrm{Zr}\left(\mathrm{MoO}_{4}\right)_{2}$ were formed in samples with Mo surface densities above $5 \mathrm{Mo} / \mathrm{nm}^{2}$. Treatment in air at temperatures below $873 \mathrm{~K}$ leads to the preferential formation of $\mathrm{MoO}_{3}$, while higher temperatures favor the solid-state reaction between $\mathrm{MoO}_{3}$ and $\mathrm{ZrO}_{2}$ to form exclusively $\mathrm{Zr}\left(\mathrm{MoO}_{4}\right)_{2}$.

Acknowledgment. We acknowledge Dr. George D. Meitzner for his expert help in the acquisition and analysis of X-ray absorption data. This work was supported by the Director, Office of Basic Energy Sciences, Chemical Sciences Division of the U.S. Department of Energy (DOE) under Contract DE-AC0376SF00098. X-ray absorption data were collected at the Stanford Synchrotron Radiation Laboratory (SSRL), which is operated by the Department of Energy, Office of Basic Energy Sciences.

\section{References and Notes}

(1) Albonetti, S.; Cavani, F.; Trifiro, R. Catal. Rev.-Sci. Eng. 1996, 38,413 and references therein.

(2) Blasko, T.; Lopex Nieto, J. M. Appl. Catal. 1997, 157, 117.

(3) Kung, H. H. Adv. Catal. 1994, 40, 1.

(4) Cavani, F.; Trifiro, F. Appl. Catal. 1995, 133, 219.

(5) Mamedov, E. A.; Cortes-Corberan, V. Appl. Catal. 1995, 127, 1.

(6) Busca, G. Catal. Today 1996, 27, 457.

(7) Deo, G.; Wachs, I. E. J. Phys. Chem. 1991, 95, 5889

(8) Centi, G.; Trifiro, F. Appl. Catal. A: General 1996, 143, 3.

(9) Michalakos, P.; Hung, M. C.; Jahan, I.; Kung, H. H. J. Catal. 1993, 140, 226.

(10) Khodakov, A.; Yang, J.; Su, S.; Iglesia, E.; Bell, A. T. J. Catal. 1998, 177, 343 421

(11) Chen, K. D.; Xie, S.; Bell, A. T.; Iglesia, E. J. Catal. 2000, 189,

(12) Stencel, J. M. Raman Spectroscopy for Catalysis; van Nostrand Reinhold: New York, 1990.

(13) Schrader, B., Ed. Infrared and Raman Spectroscopy: Methods and Applications; VCH: Weinheim, 1995.

(14) Mestl, G.; Srinivasan, T. K. K. Catal. Rev. 1998, 40, 451.
(15) Hardcastle, F. D.; Wachs, I. E. J. Raman Spectrosc. 1990, 21, 683. (16) Meitzner, G. D. Catal. Today 1998, 39, 281.

(17) Barton, D. G. Ph.D. Thesis, University of California at Berkeley, 1998.

(18) Ressler, T. J. Phys. IV 1997, 7, 269.

(19) Ressler, T. J. Synch. Rad. 1998, 5, 118.

(20) Hillerová, E.; Morishige, H.; Inamura, K.; Zdrazil, M. Appl. Catal. A: Gene. 1997, 156, 1.

(21) Prinetto, F.; Cerrato, G.; Ghiotti, G.; Chiorino, A.; Campa, M. C.; Gazzoli, D.; Indovina, V. J. Phys. Chem. 1995, 98, 5556.

(22) Sonnemans, J.; Mars, P. J. Catal. 1973, 31, 209.

(23) Xie, Y.; Tang, Y. Adv. Catal. 1990, 37, 1.

(24) Wang, X.; Zhao, B.; Jiang, D.; Xie, Y. Appl. Catal. A: Gene 1999, 188,201

(25) Liu, Z.; Chen, Y. J. Catal. 1998, 177, 314.

(26) Liu, Z.; Dong, L.; Chen, Y. J. Chem. Soc., Faraday Trans. 1998, 94, 1137.

(27) Del Arco, M.; Carrazán, S. R. G.; Rives, V.; Gil-LlambRas, F. J.; Malet, P. J. Catal. 1993, 141, 48.

(28) Dufresne, P.; Payne, E.; Grimblot, J.; Bonnelle, J. P. J. Phys. Chem. 1981, 85, 5, 2344

(29) Zingg, D. S.; Makovsky, L. E.; Tischer, R. E.; Brown, F. R.; Hercules, D. M. J. Phys. Chem. 1980, 84, 2898.

(30) Edwards, J. C.; Adams, R. D.; Ellis, P. D. J. Am. Chem. Soc. 1990, 112,8349

(31) Xie, S.; Iglesia, E.; Bell, A. T. Chem. Mater. 2000, 12, 2442.

(32) Etsell, T. H.; Flengas, S. N. Chem. Rev. 1970, 70, 339.

(33) Barton, D. G.; Soled, S. L.; Meitzner, G. D.; Fuentes, G. A.; Iglesia, E. J. Catal. 1999, 181, 57.

(34) Xie, S.; Iglesia, E.; Bell, A. T. Unpublished results.

(35) Auray, M.; Quarton, M.; Tarte, P. Acta Crystallogr. 1986, C42, 257.

(36) Nakamoto, K. Infrared and Raman Spectra of Inorganic and Coordination Compounds, 4th ed.; John Wiley \& Sons: New York, 1986; pp130-141.

(37) Herzberg, G.; Molecular Spectra and Molecular Structure; van Nostrand: New York, 1945.

(38) Weinstock, N.; Schulze, H.; Müller, A. J. Chem. Phys. 1973, 59 , 5063.

(39) Li, W.; Meitzner; G. D.; Borry, R. W.; Iglesia, E. J. Catal. 2000 $191,373$.

(40) Shadle, E.; Hedman, B.; Hodgson, K. O.; Solomon, E. I. Inorg. Chem. 1994, 33, 4235.

(41) Vuurman, M. A.; Wachs, I. E. J. Phys. Chem. 1992, 96, 5008.

(42) Jeziorowski, H.; Knözinger, H. J. Phys. Chem. 1979, 83, 1166.

(43) Cheng, C. P.; Schrader, G. L. J. Catal. 1979, 60, 276.

(44) Wang, L.; Hall, W. K. J. Catal. 1980, 66, 251.

(45) Wachs, I. E. Catal. Today 1996, 27, 437.

(46) Chan, S. S.; Wachs, I. E.; Murrell, L. L.; Wang, L.; Hall, W. K. J. Phys. Chem. 1984, 88, 5831 .

(47) Miyata, H.; Tokuda, S.; Ono, T.; Ohno, T.; Hatayama, F. J. Chem Soc. Faraday Trans. 1990, 86, 2291.

(48) Payen, E.; Kasztelan, S.; Grimblot, J.; Bonnelle, J. P. J. Raman Spectrosc. 1986, 17, 233.

(49) Stencel, J. M.; Makovsky, L. E.; Sarkus, T. A.; de Vries, J.; Thomas, R.; Mouljin, J. A. J. Catal. 1984, 90, 314.

(50) Knözinger, H.; Jeziorowski, H. J. Phys. Chem. 1979, 83, 1166

(51) Weber, R. S. J. Catal. 1995, 151, 470.

(52) Xiong, G.; Li, C.; Feng, Z.; Ying, P.; Xin, Q.; Liu, J. J. Catal. 1999, 186, 234 .

(53) Collin, R. J.; Griffith, W. P.; Pawson, D. J. Mol. Struct. 1973, 19, 531.

(54) Alexander, L. E.; Beattie, I. R.; Bukovszky, A.; Jones, P. J.; Marsden, C. J.; van Schalkwyk, G. J. J. Chem. Soc., Dalton Trans. 1974, 81

(55) Paiine, R. T.; McDowell, R. S. Inorg. Chem. 1974, 13, 2366.

(56) Beatties, I. R.; Livingston, K. M. S.; Reynolds, D. J.; Ozin, G. A. J. Chem. Soc. A 1970, 1210 .

(57) Iijima, K.; Shibata, S. Bull. Chem. Soc., Jpn. 1975, 48, 666.

(58) Desikan, A. D.; Huang, L.; Oyama, S. T. J. Chem. Soc., Faraday Trans. 1992, 88, 3357.

(59) Mercera, P. D. L.; van Ommen, J. G.; Doesburg, E. B. M.; Burggraaf, A. J.; Ross, J. R. H. Appl. Catal. 1990, 57, 127.

(60) Murase, Y.; Kato, E. J. Am. Ceram. Soc. 1983, 66, 196.

(61) Ma, E. Bull. Chem. Soc. Jpn. 1964, 37, 648.

(62) Xie, S.; Bell, A. T.; Iglesia, E. Unpublished results

(63) Aritani, H.; Tanaka, T.; Funabiki, T.; Yoshida, S.; Kudo, M.; Hasegawa, S. J. Phys. Chem. 1996, 100, 5440.

(64) Verbruggen, N. F. D.; Mestl, G.; von Hoppel, L. M. J.; Lengeler, B.; Knözinger, H. Langmuir 1994, 10, 3063.

(65) Takenaka, S.; Tanaka, T.; Funabiki, T.; Yoshida, S. J. Phys. Chem B 1998, 102, 2960. 